\title{
Late Quaternary erosion in southeastern Australia: a field example using cosmogenic nuclides
}

\author{
Arjun M. Heimsath ${ }^{\mathrm{a}, *}$, John Chappell ${ }^{\mathrm{b}}$, William E. Dietrich ${ }^{\mathrm{c}}$, Kunihiko Nishiizumi ${ }^{\mathrm{d}}$, \\ Robert C. Finkel ${ }^{\mathrm{e}}$ \\ ${ }^{a}$ Department of Earth Sciences, Dartmouth College, Hanover, NH 03755, USA \\ ${ }^{\mathrm{b}}$ Research School of Earth Sciences, Australian National University, Canberra, ACT 0200, Australia \\ ${ }^{\mathrm{c}}$ Department of Geology and Geophysics, University of California, Berkeley, CA 94720, USA \\ ${ }^{\mathrm{d}}$ Space Sciences Laboratory, University of California, Berkeley, CA 94720, USA \\ ${ }^{\mathrm{e}}$ Center for Accelerator Mass Spectrometry, Lawrence Livermore National Laboratory, Livermore, CA 94550, USA
}

Accepted 29 May 2001

\begin{abstract}
Late Quaternary rates of apparent soil production, bedrock incision, and average erosion are determined for the southeastern highlands of Australia using in situ produced cosmogenic nuclide concentrations of ${ }^{10} \mathrm{Be}$ and ${ }^{26} \mathrm{Al}$. Apparent soil production rates define a steep, inverse exponential function of soil depth with a maximum of $143 \mathrm{~m} \mathrm{Ma}^{-1}$ under zero soil depth. There were no observed soil depths between about $25 \mathrm{~cm}$ and zero, however, such that the maximum observed rate is about $50 \mathrm{~m} \mathrm{Ma}^{-1}$. The Bredbo River catchment average erosion rate is $15 \pm 1 \mathrm{~m} \mathrm{Ma}^{-1}$, and is similar to the average hillslope erosion rate of $16 \pm 1 \mathrm{~m} \mathrm{Ma}{ }^{-1}$. Bedrock incision rates average $9 \mathrm{~m} \mathrm{Ma}^{-1}$ and suggest that the higher rates of hillslope erosion may be in response to a pulse of incision, perhaps generated by knickpoint propagation. Bedrock erosion rates inferred from a tor profile average $3.8 \mathrm{~m} \mathrm{Ma}^{-1}$, with higher rates on other, more weathered tor tops. An aboveground tor profile of nuclide concentrations is consistent with a simple model of rapid stripping of the surrounding saprolite, supporting the view that at least one episodic period of increased denudation has affected the landscape evolution of the highlands. We test this hypothesis by using a simple landscape evolution model to reasonably predict the spatial variation of soil depth as well as the emergence of tors. (C) 2001 Elsevier Science Ltd and INQUA. All rights reserved.
\end{abstract}

\section{Introduction}

Landscape evolution depends on the balances between uplift, the processes that remove sediment from the landscape, and the material properties of the landscape. If tectonic uplift did not replace the eroded landscape monotonically, then the declining relief model of Davis (1899) would hold and the landscape would essentially wear down to a broad peneplain. If, however, all parts of the landscape eroded at the same rate, equal to the uplift of the region, then the dynamic equilibrium theory of the landscape as first articulated by Gilbert $(1877,1909)$ and then Hack (1960) would be applicable and landscape morphology would be time-independent. These theories are likely to represent end members for

\footnotetext{
*Corresponding author. Tel.: + 1-603-646-2374; fax: + 1-603-6463922.

E-mail address: arjun.heimsath@dartmouth.edu (A.M. Heimsath).
}

the spectrum of actual conditions of landscape evolution, where climate and tectonic forces acting over a range of temporal and spatial scales drive erosional processes. Furthermore, landscapes evolve into forms that reflect the variable properties of the underlying bedrock that may contribute to local disequilibrium in erosion rates.

Irrespective of where on the landscape evolution spectrum any given landscape lies, two of the fundamental parameters defining the rate of landscape evolution are the conversion rates of bedrock to removable material (soil production) and the rates of removal of the material. In bedrock landscapes the rates are identical and the landscape is weathering-limited (Carson and Kirkby, 1972). On soil mantled, hilly landscapes the rates can be equal if the local soil thickness does not change with time. The pace of landscape change thus depends on the erosion rates imposed on the landscape, which depend on local 
conditions such as vegetation, burrowing animals, precipitation, and temperature. Under these conditions, the rate of change is transport-limited (Carson and Kirkby, 1972), and to remain soil mantled landscapes must be producing soil at rates at least equal to the erosion rates. Hillslope erosion rates are typically driven by the incision rates of the rivers or streams into the landscape, which are in turn dependent on the tectonic uplift and the climate of the region. Soil production rates therefore help set the landscape lowering rates and can determine how soil mantled landscapes respond to the changes in the erosion rates (Heimsath et al., 1997, 1999, in press).

This paper tackles two areas of continuing debate in Australian Quaternary Studies. The first examines the rates of denudation of a site in the southeastern highlands; the second examines geomorphic processes responsible for these rates. Specifically, we report cosmogenic nuclide concentrations $\left({ }^{10} \mathrm{Be}\right.$ and $\left.{ }^{26} \mathrm{Al}\right)$ from a variety of samples to determine apparent soil production, bedrock tor erosion, river incision, and catchment-averaged erosion rates from a field site in the southeastern highlands of New South Wales (NSW). We couple these measurements with a numerical model which predicts nuclide concentrations for the profile of emergent tors, as well as with detailed topographic and soil thickness measurements, to examine the nature and timing of the hillslope erosion processes. We use field data together with the tor model and a model that predicts soil thickness to test the hypothesis of Butler $(1959,1967)$ that changing climates of the Pleistocene in southeast Australia led to cyclic episodes of soil stripping and regeneration. Our results from the southeastern highlands are consistent with there being one or more pulses of increased incision into the landscape, leading to rapid removal of weathered bedrock. Finally, these results are compared to measurements (Heimsath et al., in press) from the base of the passive margin escarpment, which separates the southeastern highlands from the coastal lowlands, to suggest differences in the landscape evolution between the two sites.

\section{Southeastern Australia setting}

Southeastern Australia has been the subject of continued debate over the timing, nature, and extent of denudation and landscape evolution. Evolution of the present topography may have been initiated by rifting between the Australian continent and the Lord Howe Rise 85-100 million years ago (Hayes and Ringis, 1973; Weissel and Hayes, 1977; Ollier, 1982; Wellman, 1987; Gilchrist and Summerfield, 1990; Seidl et al., 1996; O'Sullivan et al., 1999). The highland region of relatively low-relief is considered to have been subject to relatively slow erosion $\left(\sim 10 \mathrm{~m} \mathrm{Myr}^{-1}\right)$ (Ollier, 1978; Bishop, 1985; Bishop et al., 1985; Pain, 1985; Wellman,
1987; Bishop and Brown, 1992; Nott, 1992). This is separated from the coastal belt by what is commonly referred to as the Great Escarpment (Ollier, 1982, 1985). Fission track ages from the coastal region suggest higher denudation rates, on the order of $20 \mathrm{~m} \mathrm{Myr}^{-1}$ (Moore et al., 1986; Dumitru et al., 1991; van der Beek and Braun, 1998).

Long-term rates may have changed in Pleistocene times. On the basis of soil stratigraphy, Butler (1959, 1967) considered that erosional processes in the southeastern highlands alternated between periods of landscape stability and instability, in response to cyclical climatic changes. While Butler's soil stratigraphic scheme has been questioned (e.g. Bowler, 1967), field evidence indicates that erosion across the highlands was episodic. Studies of buried and relic geomorphic surfaces have shown how rates and processes have changed in pulses, but have also shown that they can occur without climate changes (e.g. van Dijk, 1959; Walker, 1962; Coventry and Walker, 1977; Prosser et al., 1994). It has also been shown that periglacial processes, thought to be more erosive than processes under milder climates, occurred in the southeastern highlands during the last glacial cycle (Galloway, 1965; Caine and Jennings, 1968; Costin and Polach, 1971; Costin, 1972), and presumably similar processes were active in previous glacial periods.

\section{Field site}

The work presented here is based on a typical upland site in the southeastern highlands (Fig. 1). Frogs Hollow $(\mathrm{FH})$ is at an elevation of $930 \mathrm{~m}, 80 \mathrm{~km}$ south-southeast of Canberra, $75 \mathrm{~km}$ from the coast, and about $12 \mathrm{~km}$ west of the escarpment. Bedrock varies across the region between Ordovician metasediments and Devonian granites (Fig. 1) (Richardson, 1976). With the exception of granitic tors, the surface morphology of the plateau regions of the highlands is similar across bedrock types and is characterized by low relief hillslopes (roughly less than $100 \mathrm{~m}$ ) that are gently sloping (less than $25^{\circ}$ ) and are thinly soil mantled. There are also dissected ranges of higher relief separating such highlands which are not examined here. The climate is relatively cool, averaging about $18-22^{\circ} \mathrm{C}$ in summer and $5-8^{\circ} \mathrm{C}$ in winter, with short periods of freezing temperatures and snow occurring in winter. Rainfall is not seasonal and, with the exception of drought periods, averages between 550 and $750 \mathrm{~mm} / \mathrm{yr}$ (Bureau of Meteorology, 1999). Forest cover, where it occurs, is typically dry schlerophyll, with very little understory. Land clearing for farming has produced widespread grassland and rolling savanna woodland.

Soil production and erosion appear to be primarily due to biogenic processes and creep, although there is 

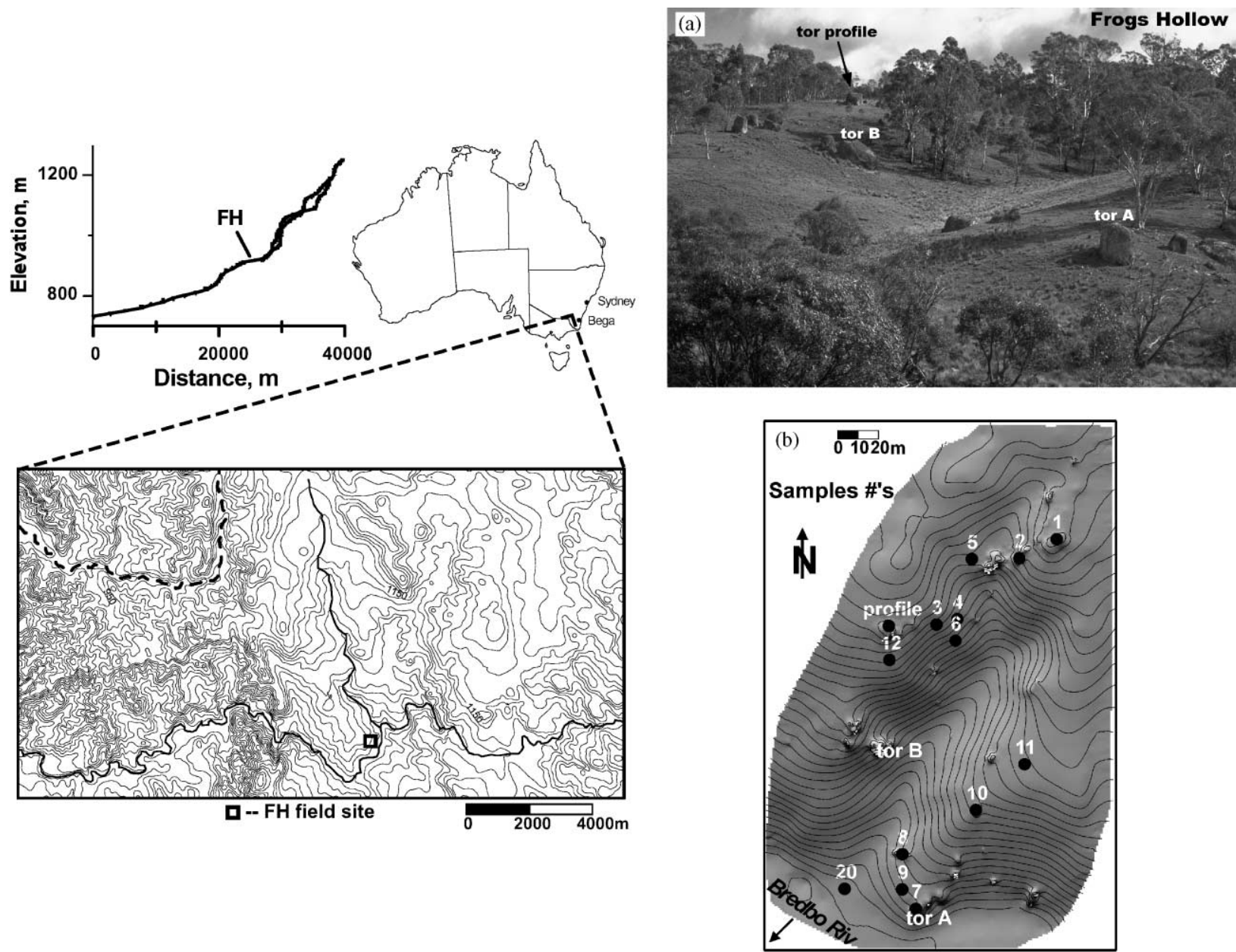

Fig. 1. Site location with the inset map of regional topography drawn with $20 \mathrm{~m}$ contours from $1: 100,000$ digital data from AUSLIG (Australian Surveying and Land Information Group) from the Michelago map (sheet 8726). Bottom right corner of the contour map is located by $36^{\circ} \mathrm{S}$ latitude and $149^{\circ} 30^{\prime}$ East longitude. Inset longitudinal profile is of the Bredbo River and a tributary upstream of the Frogs Hollow site (FH), with zero set east of the boundary of the inset map. Location of FH is shown by the open square. The Bredbo (right branch) and tributary are drawn with thickened solid black line on the contour map. The dashed line highlights Wangrah Creek, used in the study by Prosser et al. (1994). (a) Photograph of the site looking north from the south side of the Bredbo River. Tors A an B and the arrow to the tor profile help locate the features on the photograph on the shaded relief map of the site, (b), which shows the spatial distribution of the FH nuclide samples (Table 1). Contour data for (b) are from (a) from our laser total station survey and are drawn at $1 \mathrm{~m}$ intervals, from $910 \mathrm{~m}$ elevation at the catchment mouth at the bottom of the page to $947 \mathrm{~m}$ at the catchment boundary near the top of the page.

evidence of overland flow. Drier and colder climates of the Pleistocene may have reduced the rate of bioturbation, but rates and processes of cryoturbation would have increased. Burrowing wombats are the most obvious cause of bioturbation today and occupy all parts of the landscape except where soil thickness is less than about $30 \mathrm{~cm}$. Other factors include burrowing echidnas, soil-scraping lyrebirds, tree throw, and microfauna such as worms (see Paton et al., 1995 for review). Overland flow was indicated by sediment deposited behind sticks and shallow scour downslope of trees and tors. The absence of rilling on the hillslopes and occurrence of wash deposits in the hollows suggested that rainwash may not be a dominant factor in the sediment transport on the site today.
The undulating hills of $\mathrm{FH}$ are punctuated by tors, standing up to $3 \mathrm{~m}$ above the ground surface (Figs. 1 and 2), similar to bedrock tors in other saprolitic granite landscapes described by Linton (1955), Twidale (1985), and Williams et al. (1986). The weathered nature of the soil-mantled saprolite is exposed in local road-cuts, which also reveal granite core-stones, some of which are likely to emerge in the future as tors. The soil mantle appears universally thin $(<1 \mathrm{~m})$ throughout the region on divergent ridges. Unchanneled mid-slope hollows typically have fills less than $2 \mathrm{~m}$ thick, whereas Prosser et al. (1994) report relatively thick valley fills ( $>5 \mathrm{~m}$ in places) from a nearby area in metasediment bedrock.

Base level at FH is set by the Bredbo River, a tributary to the Murrimbidgee River. The catchment has 


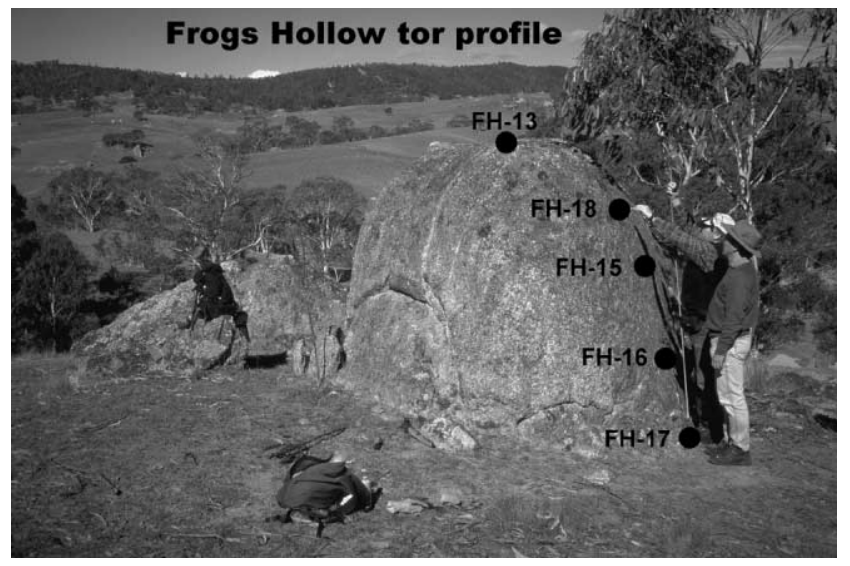

Fig. 2. Photograph looking south along the north ridge crest of FH that shows the tor used for the tor emergence model (Fig. 3) and the sample locations for each of the tor profile nuclide samples.

a local relief of $\sim 30 \mathrm{~m}$ and drains to a relatively flat reach between two knickpoints on the Bredbo River (Fig. 1). Both knickpoints occur in granite, apparently no different from that found elsewhere in the Bredbo River channel, and the upper knickpoint occurs at the same distance upstream of $\mathrm{FH}$ in two roughly equal tributaries. Together, these observations suggest that the knickpoints are propagating upstream rather than being fixed reaches over more resistant rock.

\section{Theory}

Here we apply the theory developed initially in northern California (Heimsath et al., 1997, 1999) and subsequently expanded to include an important test for steady-state landscape lowering using outcropping granite tors (Heimsath et al., in press). This conceptual framework is reviewed briefly here.

\subsection{Cosmogenic nuclides}

Our geomorphologic rate determinations here are based on concentrations of the cosmogenic nuclides, ${ }^{10} \mathrm{Be}$ and ${ }^{26} \mathrm{Al}$, produced in situ in bedrock, saprolite, and river or catchment sediments (see reviews in Lal, 1991; Nishiizumi et al., 1993; Bierman, 1994; Cerling and Craig, 1994; Bierman and Steig, 1996). Nuclide concentrations measured from quartz have been shown to reflect the exposure history of the sample and are dependent on the production and decay rates of the nuclide, as well as the erosion rate of the sample (Lal and Arnold, 1985; Nishiizumi et al., 1986; Lal, 1988; Nishiizumi et al., 1991). As shown by Lal (1991), and neglecting muon effects, the nuclide concentration, $C$, depends on the production of the nuclide as an exponential depth $\left(z_{x}\right)$ function of the surface production rate, $P_{0}$, and its radioactive decay constant, $\lambda$,

$\frac{\mathrm{d} C}{\mathrm{~d} t}=P_{0} \mathrm{e}^{-\mu z_{x}}-\lambda C$,

where $\mu$ is the absorption coefficient (equal to material density divided by the mean attenuation length for cosmic rays, $\Lambda$, where $\Lambda \sim 165 \mathrm{~g} \mathrm{~cm}^{-2}$ ), and $\lambda=\ln 2 / t_{1 / 2}$, where $t_{1 / 2}=1.5 \times 10^{6} \mathrm{yr}$ for ${ }^{10} \mathrm{Be}$ and $t_{1 / 2}=7.01$ $\times 10^{5} \mathrm{yr}$ for ${ }^{26} \mathrm{Al}$ ). If erosion $(\varepsilon$, normal to the surface of exposed bedrock, $\varepsilon_{\mathrm{r}}$, and to the soil-saprolite interface, $\varepsilon_{\mathrm{s}}$ ) is assumed to be constant over the exposure history of the sample, Eq. (1) can be solved analytically (Lal, 1991), giving

$C=C_{0} \mathrm{e}^{-\lambda t}+P(H, \theta)\left(\frac{-1}{\lambda+\mu \varepsilon}\right)$

at secular equilibrium, when $t \gg(\lambda+\mu \varepsilon)^{-1}$, where $P(H, \theta)$ is the nuclide production rate $\left(\right.$ atom $\left.^{-1} \mathrm{yr}^{-1}\right)$ at the soil-bedrock boundary under slope-normal soil depth, $H$, and on a surface with slope, $\theta$, and $C_{0}$ is the initial concentration of the nuclide. $P(H, \theta)$ is calculated as a factor of the surface nuclide production rates (Dunne et al., 1999), discussed above. Under steady state conditions, soil production, $\varepsilon_{s}$, equals erosion, $\varepsilon$, at the surface which is also equal to the rate of lowering of the soil-saprolite interface. Eq. (2) can therefore be solved to yield steady-state soil production or erosion rates. Nuclide concentration accumulated in river or catchment sediments can be interpreted by Eq. (2) to infer catchmentaveraged steady-state erosion rates assuming relatively short transport times and relatively homogeneous catchment lithology (e.g. Bierman and Steig, 1996).

\subsection{Soil production, transport, and topography}

The conceptual framework of Dietrich et al. (1995) was developed by Heimsath et al. (1997, 1999, in press) to examine the relationship between soil production, topographic curvature and soil thickness. The continuity equation for a vertical column of soil, $h$, neglecting mass loss to solution, is

$\rho_{\mathrm{s}} \frac{\partial h}{\partial t}=-\rho_{\mathrm{r}} \frac{\partial z_{\mathrm{b}}}{\partial t}-\nabla \tilde{q}_{\mathrm{s}}$,

where the vertical lowering rate of the soil-bedrock boundary, $-\partial z_{\mathrm{b}} / \partial t$, at any point on the landscape is equivalent to the slope-normal soil production rate, $\varepsilon(H)$, times the secant of the slope angle, $\theta$ (for moderate slopes $\sec (\theta) \sim 1)$ (Heimsath et al., 1997, in press). When sediment transport is by creep such that the transport flux is proportional to slope, $\tilde{q}_{\mathrm{s}}=$ $-\rho_{\mathrm{s}} K \nabla z$, as proposed initially by Davis (1892) and Gilbert (1909), and assuming that soil thickness at any point is constant (i.e. $\partial h / \partial t=0$ ) then Eq. (3) reduces to a simple relationship between soil production and 
topographic curvature

$\varepsilon(h)=-\frac{\rho_{\mathrm{s}}}{\rho_{\mathrm{r}}} K \nabla^{2} z$,

where $K$ is a diffusion coefficient with dimensions $L^{2} T^{-1}, z$ is the ground surface elevation, and $\varepsilon(h)$ is the soil production rate. Bulk densities of soil and rock, respectively, are $\rho_{\mathrm{s}}$ and $\rho_{\mathrm{r}}$.

\subsection{Modeling soil depth variation}

To test the hypothesis that observed soil depths could have developed since potential stripping events due to Pleistocene increases in sediment transport rates, we applied the model proposed by Dietrich et al. (1995) to predict soil depth across the surveyed area under very simple conditions. The model solves Eq. (3) by finite differences such that the soil production and sediment flux rates adjust at every time step as functions of the local soil depth and surface topography. The soil production function used in the model is determined from nuclide concentrations in the eroding saprolite. For comparison we also used the soil production function determined from the Bega Valley field site of Heimsath et al. (in press). Diffusivity, $K$, was estimated to be $40 \mathrm{~cm}^{2} \mathrm{yr}^{-1}$ at that field site by Heimsath et al. (in press) and is used here because biogenic processes in the two areas are similar. The model procedure followed Heimsath et al. (1999) with tors added as an initial condition. The model specifies the initial soil depth across the current landsurface, and we added discrete blocks defining the locations of the observed tors (Fig. 4), which are set to erode with an order of magnitude lower rate than the surrounding saprolite under zero soil depth. Sediment at the lower boundary of the model was removed automatically to simulate removal of material by the Bredbo River. Soil depths predicted by the model are compared to soil depths measured at each of the filled circles shown in Fig. 3.

\subsection{Tor erosion rates: a test of steady state}

We used a numerical model that predicts nuclide concentrations on emergent tor profiles as a function of the exhumation history (Heimsath et al., in press) (Fig. 4). Specifically, Eq. (1) is integrated numerically using standard Runge Kutta methods with $z_{x}(t)$ substituted for $z_{x}$ to represent a given erosion history. Two patterns of tor exposure history are considered: (I) a steady-state model where the rates of ground surface lowering, $\varepsilon_{\mathrm{s}}$, and tor erosion, $\varepsilon_{\mathrm{r}}$, are held constant while the more slowly eroding tor emerges from the lowering soil-mantled landscape; (II) an episodic model where initial steady-state erosion prior to tor emergence $\left(\varepsilon_{\mathrm{s}}=\right.$ $\varepsilon_{\mathrm{r}}$ ) is followed by a period of "stripping" that rapidly exposes the entire tor surface that erodes at rate, $\varepsilon_{\mathrm{r}}$, once

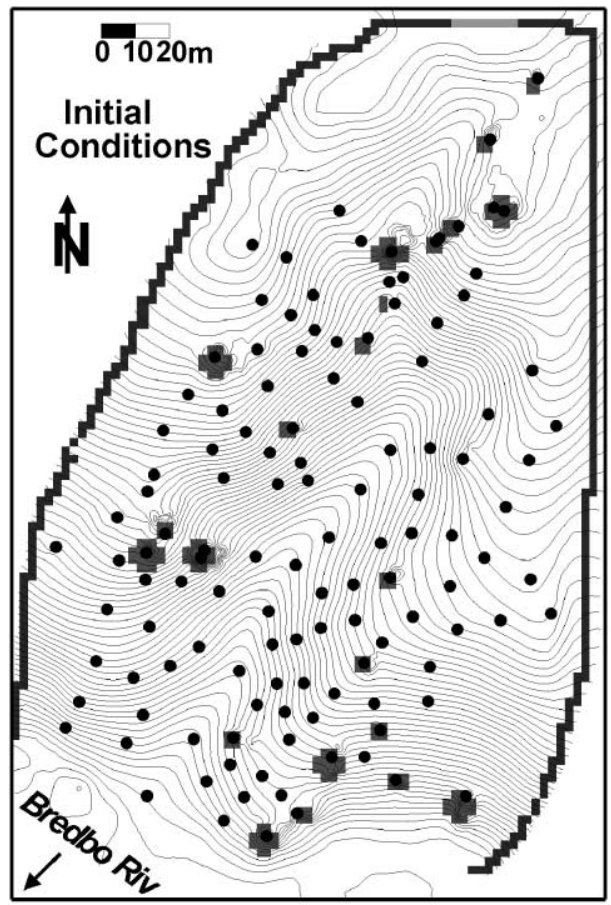

Fig. 3. Contour map of the field site, FH, drawn with $0.5 \mathrm{~m}$ contour intervals to show detailed location of the surveyed tors, the soil pit and depth measurements (filled circles), and the locations of the corestones (gray patches) placed for the initial conditions of the landscape evolution model.

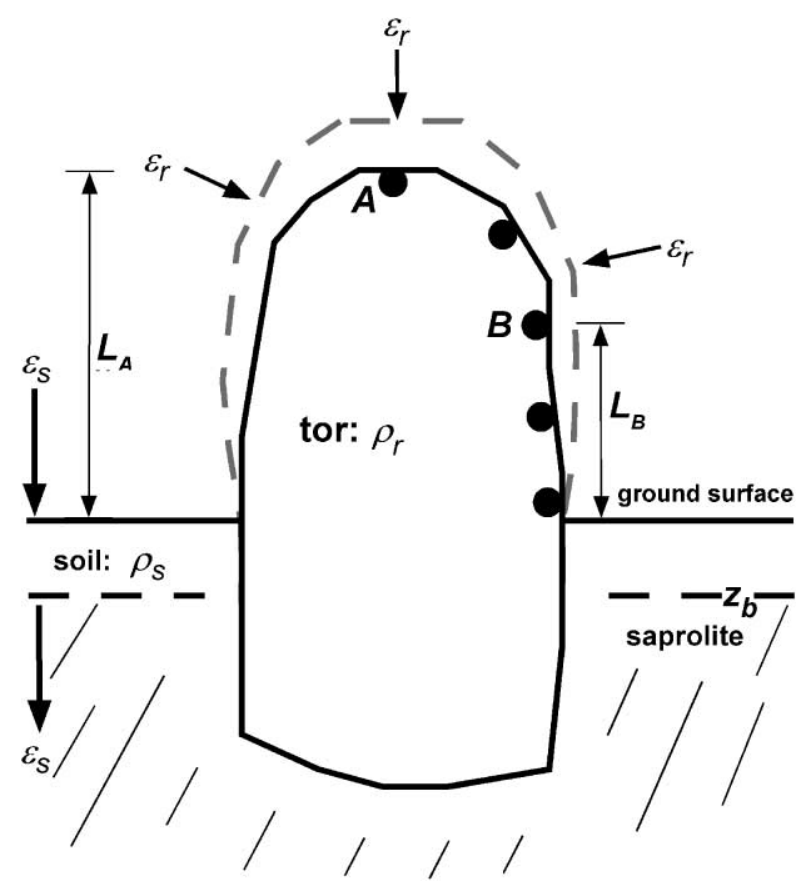

Fig. 4. A model for tor emergence where the tor is eroding uniformly from all sides at rate, $\varepsilon_{\mathrm{r}}$, and the ground surface is lowering at a constant rate, $\varepsilon_{\mathrm{s}}$. The dashed line surrounding the aboveground tor illustrates only the erosion of the tor surface since emergence from the ground; for modeling the accumulation of nuclides in the tor surfaces, the weathering rate below ground is equivalent to the soil production rate. Modified from Heimsath et al. (in press). 
exposed. Predicted nuclide concentrations are compared to concentrations measured from a tor profile at the ridge crest of FH (Figs. 1 and 2) and both predicted and observed concentrations are corrected for the shielding and slope of the tor.

\section{Methods}

\subsection{Cosmogenic nuclides}

Soil pits across the full range of observed soil thickness were used to collect samples from the soilsaprolite boundary, and each sample was taken from the top $5 \mathrm{~cm}$ of the continuous layer of saprolite. Bulk densities of the saprolite and the overlying soil at each site were measured with a known volume cylindrical corer. Soil thickness was constant within each pit and was measured normal to the slope. Samples of channel sand were collected from the Bredbo River, immediately downstream of the study area, and from the study catchment mouth (point 20 on Fig. 1a) to estimate the average erosion rate from the catchment areas upstream of the sampling sites (e.g. Bierman and Steig, 1996). Fluvially sculpted bedrock flutes in the present Bredbo River channel and bedrock surfaces obviously eroded by the current river were sampled to infer bedrock incision rates for the river. Shielding from the shallow, or absent water was assumed to be negligible.

Bedrock samples were collected from tor surfaces. We sampled a single tor at a range of heights above the ground surface, from 0.1 to $2.5 \mathrm{~m}$, ("profile" on Fig. 1b, and shown by Fig. 2), and we sampled the tops of 5 other tors at different heights above the ground surface (located by sample numbers on Fig. $1 \mathrm{~b}$ and listed in Table 1).

Roughly $300 \mathrm{~g}$ of bedrock, saprolite, or sediment from each sample were crushed, sieved to separate particles less than $1 \mathrm{~mm}$ size, and chemically purified following the procedure of Kohl and Nishiizumi (1992) to yield about $50 \mathrm{~g}$ of quartz from which $\mathrm{Be}$ and $\mathrm{Al}$ were extracted. Samples for ${ }^{10} \mathrm{Be}$ measurement were spiked with a ${ }^{9} \mathrm{Be}$ carrier solution calibrated by a Be atomic absorption standard that differed by less than $2 \%$ from the Be carrier used for the Nishiizumi et al. (1989) analyses. We measured concentrations of ${ }^{10} \mathrm{Be}$ and ${ }^{26} \mathrm{Al}$ at the LLNL-CAMS facility (Davis et al., 1990) and standardized the measurements to the ICN (ICN Biomedical, Inc.) ${ }^{10} \mathrm{Be}$ and the NBS (National Bureau of Standards, presently the National Institute of Standards and Technology, NIST) ${ }^{26} \mathrm{Al}$ standards.

Production rates for ${ }^{10} \mathrm{Be}$ and ${ }^{26} \mathrm{Al}$ in quartz were based on the sea level and high latitude production rates of 6 and 36.8 atoms $\mathrm{g}^{-1} \mathrm{yr}^{-1}$ respectively (Nishiizumi et al., 1989), and were corrected for latitude and altitude effects (Lal, 1991) as well as for the slope and shielding of the sample (Nishiizumi et al., 1989; Dunne et al., 1999; Masarik et al., 2000). These production rates were used for consistency with previous reports of erosion rates or exposure ages, despite the growing debate over production rates (e.g. Clark et al., 1995; Nishiizumi et al., 1996; Stone et al., 1998a; Dunai, 2000) and the potential contribution of muons to nuclide concentrations under moderate and high erosion rates (e.g. Brown et al., 1995; Stone et al., 1998b; Granger and Smith, in press).

The apparent rates of erosion or soil production were calculated using Eq. (2) from both ${ }^{10} \mathrm{Be}$ and ${ }^{26} \mathrm{Al}$ concentrations assuming the initial nuclide concentration was zero (Table 1)(Heimsath et al., 1997, 1999; Small et al., 1999). We correct the production rates for both ${ }^{10} \mathrm{Be}$ and ${ }^{26} \mathrm{Al}$ for the observed slope and shielding of every sample, including those taken from the tor surfaces (Dunne et al., 1999), and the correction factors used are in Table 1.

\subsection{Soil production from morphometry}

To test the relationship between soil depth and slope curvature (a proxy for soil production by Eq. (4)), we surveyed the catchment area (Fig. 1b) at a high resolution $(\sim 3 \mathrm{~m})$ with additional survey points taken on the emergent tors, and used the methods described in Heimsath et al. (1999) to calculate topographic curvature by gridding the digital elevation data (by Kriging (Cressie, 1991), using Surfer ${ }^{\circledR}$ software) and using the eight nearest elevation values. Soil depth was measured normal to the ground surface in 100 soil pits dug past the soil-saprolite interface.

\section{Results}

\subsection{Apparent soil production rates}

Results from five samples of saprolite under different depths of soil are reported here for both ${ }^{10} \mathrm{Be}$ and ${ }^{26} \mathrm{Al}$ (Table 1). Assuming that the soil depth is in steady state, these define an apparent soil production function for FH. Measured nuclide concentrations were corrected for observed soil depths, and erosion rates, calculated by Eq. (2), define a steep exponential decline of apparent soil production rates with increasing soil depth (Fig. 5). The variance-weighted best fit to these points is

$\varepsilon(H)=(143 \pm 20) \mathrm{e}^{-(0.042 \pm 0.003) H}$,

where the soil production rate, $\varepsilon(H)$, is the vertical lowering rate in Table 1 times the cosine of the slope angle and is in $\mathrm{m} \mathrm{Myr}^{-1} ; H$ is in $\mathrm{cm}$.

Two additional samples from exposed bedrock samples at the ground surface, assumed to be incipient tors, indicate hard-rock erosion rates from the ground 
Table 1

Cosmogenic nuclide concentrations and results ${ }^{\mathrm{a}}$

\begin{tabular}{|c|c|c|c|c|c|c|c|c|c|c|c|c|c|c|c|c|}
\hline \multirow[t]{2}{*}{ Sample } & \multirow[t]{2}{*}{ Depth (cm) } & \multirow[t]{2}{*}{ Slope } & \multirow[t]{2}{*}{$\begin{array}{l}H \text {-slope } \\
\text { factor }^{\mathrm{b}}\end{array}$} & \multirow[t]{2}{*}{ Elev. (m) } & \multirow[t]{2}{*}{ Wt (g) } & \multirow[t]{2}{*}{$\mathrm{Be}(\mathrm{mg})$} & \multirow[t]{2}{*}{$\mathrm{Al}(\mathrm{mg})$} & ${ }^{10} \mathrm{Be}^{\mathrm{c}}$ & \pm & ${ }^{26} \mathrm{Al}^{\mathrm{c}}$ & \pm & ${ }^{26} \mathrm{Al} /{ }^{10} \mathrm{Be}$ & \pm & \multirow[t]{2}{*}{$E\left(\mathrm{~m} \mathrm{Ma}^{-1}\right)^{\mathrm{d}}$} & \multirow[t]{2}{*}{ \pm} & \multirow[t]{2}{*}{ Age (ka) } \\
\hline & & & & & & & & \multicolumn{6}{|c|}{ Atoms/gm quartz (sea level) } & & & \\
\hline FH-3 & 0 & 18 & 0.98 & 939 & 45.889 & 0.458 & 4.76 & 219580 & 7714 & 1200788 & 47670 & 5.47 & 0.44 & 18.69 & 1.50 & 34.6 \\
\hline FH-10 & 0 & 15 & 0.98 & 925 & 51.195 & 0.459 & 5.65 & 151211 & 4750 & 882658 & 29460 & 5.84 & 0.44 & 26.42 & 2.00 & 24.6 \\
\hline FH-5 & 25 & 14 & 0.72 & 940 & 57.204 & 0.454 & 6.25 & 103217 & 4175 & 592709 & 27440 & 5.74 & 0.51 & 49.08 & 4.39 & 16.6 \\
\hline FH-6 & 37 & 18 & 0.61 & 934 & 53.91 & 0.452 & 5.72 & 99159 & 4637 & 608001 & 24520 & 6.13 & 0.57 & 49.42 & 4.63 & 16.5 \\
\hline FH-9 & 40 & 15 & 0.6 & 916 & 55.596 & 0.459 & 5.74 & 202519 & 6759 & 1059721 & 36490 & 5.23 & 0.46 & 25.99 & 2.26 & 31.2 \\
\hline FH-11 & 50 & 8 & 0.56 & 930 & 55.109 & 0.46 & 7.51 & 392381 & 22043 & 2505639 & 165653 & 6.39 & 0.56 & 11.79 & 1.04 & 66.6 \\
\hline FH-12 & 65 & 10 & 0.43 & 939 & 56.196 & 0.459 & 5.93 & 422049 & 32354 & 2637396 & 169582 & 6.25 & 0.63 & 11.05 & 1.10 & 70.9 \\
\hline \multicolumn{17}{|c|}{ Cosmogenic nuclide concentrations from TOR samples } \\
\hline FH-1 & 120 & 0 & 1 & 946 & 49.306 & 0.46 & 4.75 & 725386 & 13080 & 4053078 & 128100 & 5.59 & 0.4 & 5.26 & 0.37 & 115.3 \\
\hline FH-2 & 300 & 0 & 1 & 943 & 53.605 & 0.461 & 5.06 & 137417 & 4003 & 841019 & 24820 & 6.12 & 0.45 & 28.42 & 2.07 & 22.8 \\
\hline FH-4 & 30 & 20 & 0.98 & 937 & 46.4 & 0.46 & 4.68 & 215188 & 5771 & 838941 & 24210 & 3.90 & 0.45 & 27.31 & 2.12 & 23.8 \\
\hline FH-7 & 320 & 0 & 1 & 916 & 43.564 & 0.453 & 5.08 & 250887 & 7169 & 1451518 & 52120 & 5.79 & 0.44 & 15.81 & 1.20 & 40.6 \\
\hline FH-8 & 20 & 0 & 1 & 916 & 47.253 & 0.453 & 4.10 & 827656 & 14290 & 4502335 & 125800 & 5.44 & 0.37 & 4.62 & 0.32 & 129.9 \\
\hline FH-13 & 250 & 0 & 1 & 946 & 53.427 & 0.461 & 5.66 & 954269 & 16580 & 5947300 & 206200 & 6.23 & 0.45 & 3.65 & 0.26 & 160.1 \\
\hline FH-15 & 170 & 55 & 0.84 & 945 & 50.336 & 0.459 & 5.11 & 967778 & 19130 & 6010926 & 170700 & 6.21 & 0.43 & 3.60 & 0.25 & 162.1 \\
\hline FH-16 & 100 & 80 & 0.58 & 944 & 52.021 & 0.459 & 5.32 & 810439 & 24280 & 5159095 & 178800 & 6.37 & 0.49 & 4.33 & 0.33 & 137.4 \\
\hline FH-17 & 10 & 80 & 0.58 & 943 & 52.505 & 0.404 & 5.47 & 986196 & 29180 & 5597958 & 224900 & 5.68 & 0.45 & 3.71 & 0.29 & 158.0 \\
\hline FH-18 & 200 & 17 & 0.98 & 945 & 39.2 & 0.398 & 4.05 & 925106 & 27350 & 6123330 & 223700 & 6.62 & 0.52 & 3.57 & 0.28 & 160.0 \\
\hline \multicolumn{17}{|c|}{ Cosmogenic nuclide concentrations from river samples } \\
\hline FH-14 & $B R K$ & 8 & 0.99 & 905 & 55.445 & 0.461 & 5.91 & 419501 & 8897 & 2677421 & 76040 & 6.38 & 0.45 & 8.80 & 0.61 & 71.2 \\
\hline FH-19 & Riv & 0 & 1 & 950 & 53.103 & 0.402 & 5.83 & 256957 & 7600 & 1477744 & 33670 & 5.75 & 0.41 & 15.47 & 1.10 & 41.4 \\
\hline FH-20 & C & 0 & 1 & 930 & 55.888 & 0.404 & 5.96 & 250037 & 8186 & 1363046 & 43630 & 5.45 & 0.42 & 16.38 & 1.27 & 39.3 \\
\hline FH-21 & $B R K$ & 0 & 1 & 900 & 57.424 & 0.405 & 5.83 & 314678 & 10640 & 1836684 & 51060 & 5.84 & 0.44 & 12.45 & 0.94 & 51.1 \\
\hline FH-22 & $B R K$ & 0 & 1 & 900 & 56.162 & 0.407 & 5.64 & 430870 & 12740 & 2648814 & 65790 & 6.15 & 0.44 & 8.72 & 0.62 & 71.8 \\
\hline FH-25 & $B R K$ & 0 & 1 & 900 & 46.809 & 0.411 & 4.96 & 398532 & 14150 & 2453464 & 65220 & 6.16 & 0.47 & 9.46 & 0.72 & 66.4 \\
\hline
\end{tabular}

${ }^{a}$ Average soil density: $1.2 \mathrm{~g} / \mathrm{cm}^{3}$. Depth column is height $(\mathrm{cm})$ above ground for the tor samples. Location: $35.96 \mathrm{~S}$ Lat., 149.42 E Long.

${ }^{\mathrm{b}} \mathrm{H}$-slope factor corrects for soil depth and slope shielding for all samples (Dunne et al., 1999).

${ }^{\mathrm{c} 26} \mathrm{Al}$ and ${ }^{10} \mathrm{Be}$ concentrations from sea level production rates of 36.8 and 6 atoms g ${ }^{-1} \mathrm{yr}^{-1}$ (Lal, 1991; Nishiizumi et al., 1989).

${ }^{\mathrm{d}}$ Concentration errors include $1 \sigma$ from AMS, and all errors are propagated to $E$. 


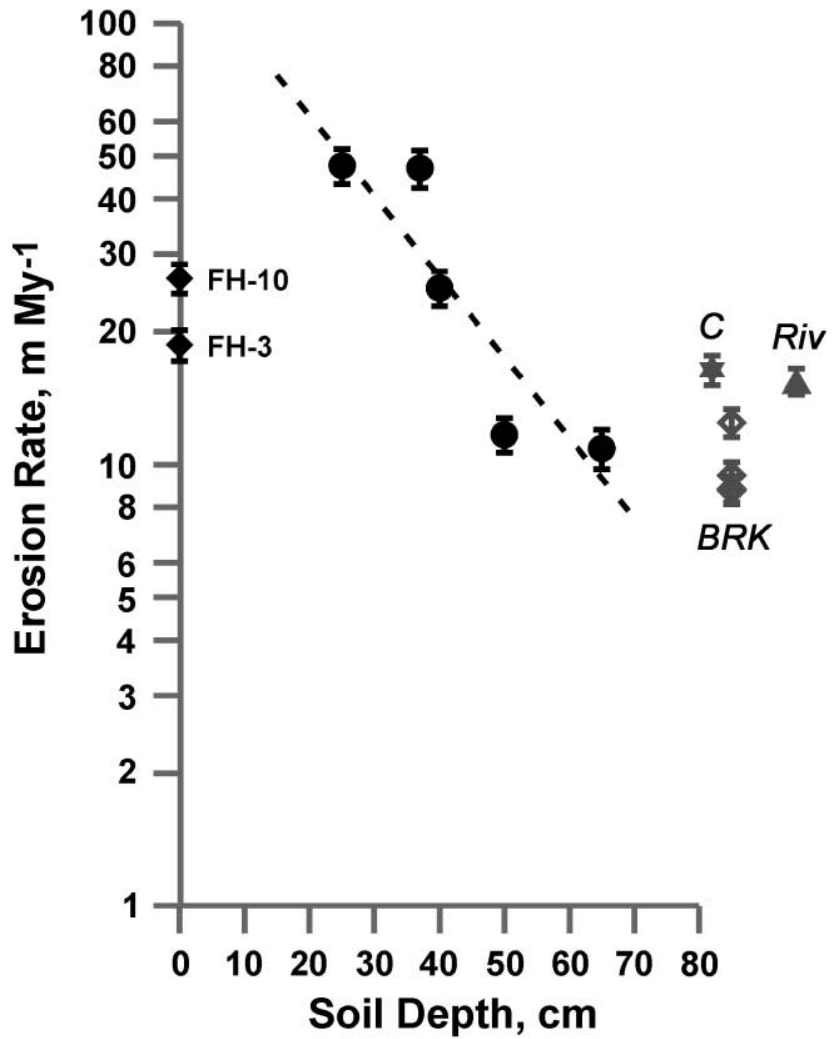

Fig. 5. Apparent soil production rates versus observed normal soil depths, $H$, for FH. Filled circles show the soil production rates versus soil depth from both ${ }^{26} \mathrm{Al}$ and ${ }^{10} \mathrm{Be}$ concentrations (Table 1). The variance weighted best fit to the filled circles is Eq. (5) in the text: $\varepsilon(H)=(143 \pm 20) \mathrm{e}^{-(0.042 \pm 0.003) H}$, where soil production is in $\mathrm{m} \mathrm{Ma}^{-1}$ and soil depth is in $\mathrm{cm}$. Black diamonds plotted at zero depth are exposed bedrock samples at the ground surface, inferred to be emerging core stones. Error bars show $1 \sigma$ error propagated from all sources or error (uncertainty in atomic absorption (AA), accelerator mass spectrometry (AMS), bulk density and soil depth measurements, and the attenuation length of the cosmic rays) except the uncertainty in nuclide production rates. Rates plotted to the right of the soil depth axis show average erosion rates from (1) sediments from the $\mathrm{FH}$ catchment area (gray star, labeled $C$ ); (2) sediments from the Bredbo River upstream of FH (gray triangle, labeled Riv); and, (3) the bedrock incision rates of the Bredbo (4) samples, gray open diamonds, labeled $B R K)$. See Table 1 for values.

surface. The erosion rates determined from these samples are plotted as zero depth samples shown by the black diamonds (Fig. 5). These results are not simple erosion rates for the exposed bedrock, however, because progressive thinning of the soil mantle must have preceded the current exposure (see discussion).

\subsection{Tor erosion and emergence}

Concentrations of ${ }^{10} \mathrm{Be}$ and ${ }^{26} \mathrm{Al}$ from a tor profile from 0.1 to $2.5 \mathrm{~m}$ above the ground surface (Fig. 2) show little variation with height (Fig. 6), which is distinctly different from results from a $2.5 \mathrm{~m}$ tor at the escarpment base in the Bega Valley (Heimsath et al., in press).
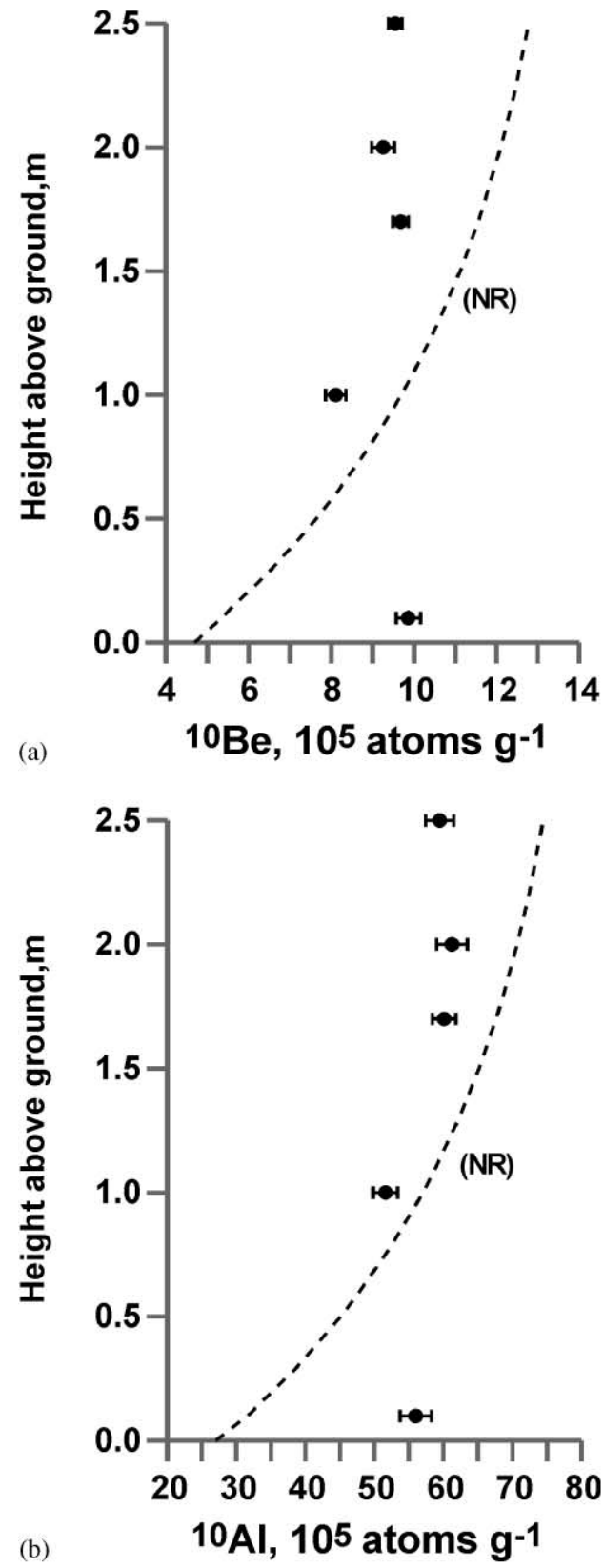

Fig. 6. Observed concentrations of (a) ${ }^{10} \mathrm{Be}$, and (b) ${ }^{26} \mathrm{Al}$ for the tor profile shown by Fig. 2. Nuclide concentrations are plotted as closed circles with height above the present ground surface, with measured nuclide concentrations normalized to sea level (Table 1) and the error bars showing $1 \sigma$ propagated from AMS, AA, bulk density, and absorption mean free path uncertainties. The black dashed line plots the best-fit model prediction for the steady-state scenario from the upper Bega Valley site of Nunnock River (NR) of Heimsath et al. (in press), scaled to fit the FH data more closely and showing the marked deviation from observed concentrations. These observations are best explained by a model that posits complete emergence of the tor early in its exposure history as discussed in the text.

There, the nuclide concentration increased upwards from the ground surface (dashed line in Fig. 6) and was consistent with the assumption that erosion rates for the tor and ground surface have been constant. Best-fit 
values indicate tor erosion of $8 \mathrm{~m} \mathrm{Myr}^{-1}$ at the Bega Valley site and ground surface erosion of $25 \mathrm{~m} \mathrm{Myr}^{-1}$ at the same spot. At FH, nuclide concentrations from the vertical profile on the $2.5 \mathrm{~m}$ high tor indicate an average tor erosion rate of $3.8 \mathrm{~m} \mathrm{Myr}^{-1}$ (FH-13, 15-18, Figs. 2 and 7; Table 1), but the fact that there is no up-profile variation suggests that the tor was rapidly exposed and has since been eroding uniformly from all directions. The timing of this stripping is discussed later.

Erosion rates inferred from nuclide concentrations from the tops of other tors (locations shown in Fig. 1b) are shown by the gray triangles in Fig. 7. The rates for FH-1 and 8 are similar to the tor profile set, but FH-2 and 7 are significantly higher. FH-2 and 7 are from two of the highest tors in the study area, which were visibly more weathered than the other tor samples, being reddened and pocked with small cavities where feldspars and quartz had fallen out, and sufficiently weakened that the samples were easily removed. In contrast, the profile tor together with FH-1 and 8, were hard, with smooth surfaces from which it was very difficult to

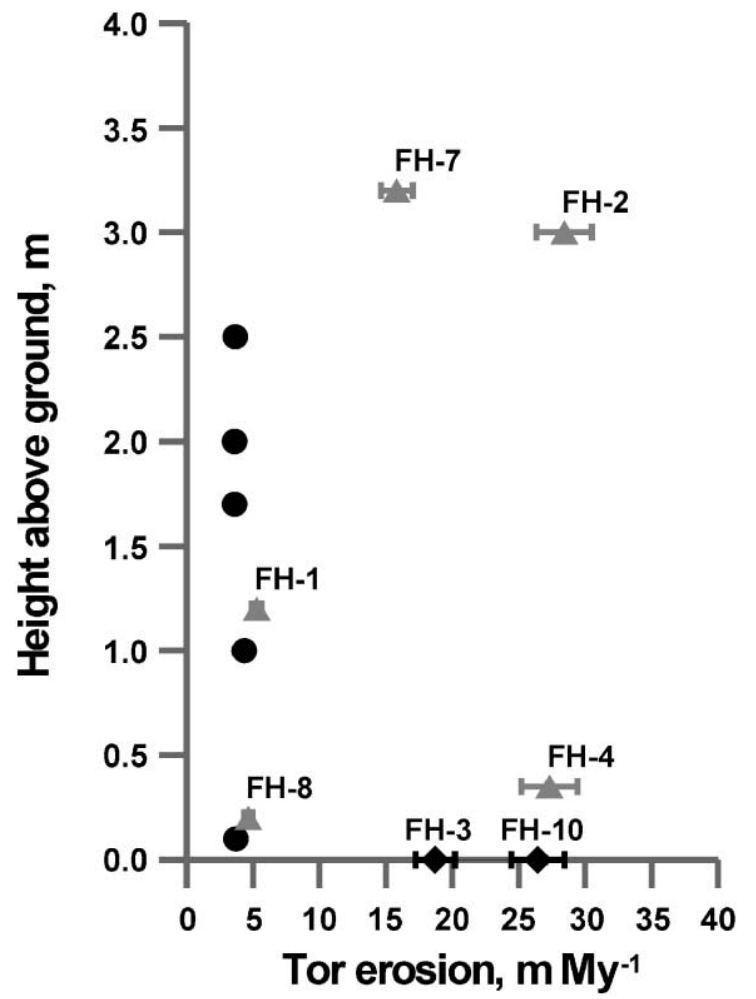

Fig. 7. The heghts of tor samples above the ground surface plotted against their constant rock erosion rates, $\varepsilon_{\mathrm{r}}$, averaged from both ${ }^{26} \mathrm{Al}$ and ${ }^{10} \mathrm{Be}$ measurements (Table 1). Filled circles show rates from the tor profile site (Figs. 2 and 6), while the gray triangles are rates from the tops of other tors, all located on the site map, Fig. 1b, with their FH sample number. The two highest tors were observed to be the most highly weathered of the tor samples. Apparent erosion rates from two exposed bedrock samples, flush with the ground surface and assumed to be incipient tors, are plotted with the black diamonds (FH-3 and 10). Error bars of the profile tor are subsumed in the symbol. remove samples. FH-4 was a tor on a side slope and may have been exhumed recently from the surrounding saprolite, thus giving a higher apparent erosion rate.

\subsection{Curvature and soil depth}

We calculated topographic curvature across the field area (Fig. 1b) from the surveyed digital elevation data using a $5 \mathrm{~m}$ grid scale (see Heimsath et al., 1999 for detailed methods), and mapped the interpolated values on Fig. 8 to show its spatial variation and therefore the potential variation for soil production rates as defined by Eq. (4). Soil depth measured in 100 pits (pit locations shown in Fig. 3) is correlated with curvature (Fig. 9) although the data show considerable scatter, especially in the divergent region (convex-up spurs). Scatter may arise because the range of soil depths is small, and because tors affect local curvature and soil transport. Despite these complications, and the differences in climate, comparison with data from the upper Bega Valley at the base of the escarpment (Heimsath et al., in press) shows good agreement (dashed line in Fig. 9). This result supports the assumption that soil moves downhill by diffusion-like processes, and thus supports

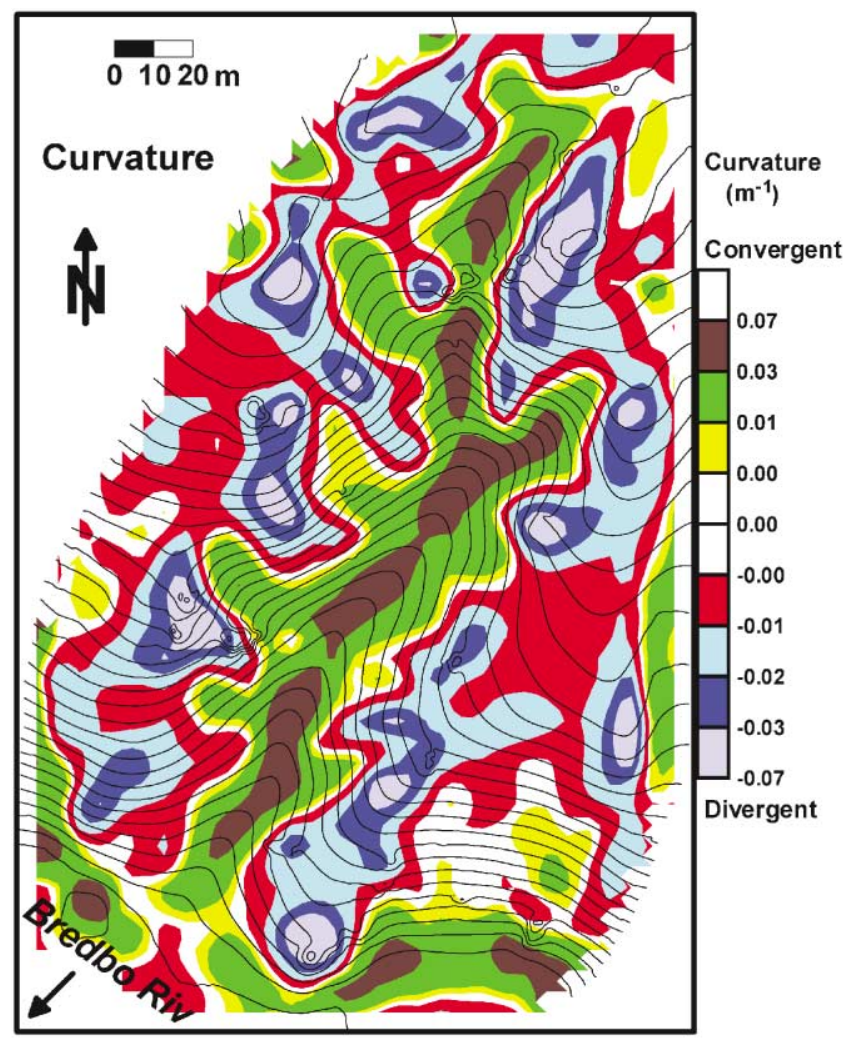

Fig. 8. The spatial variation of topographic curvature $\left(\mathrm{m}^{-1}\right)$ mapped across the FH site. Curvature was calculated by the methods described in Heimsath et al. (1999) with a $5 \mathrm{~m}$ grid, and is contoured in color here with a thin white band separating the convergent area (concave-up) from the divergent noses (convex-up). 


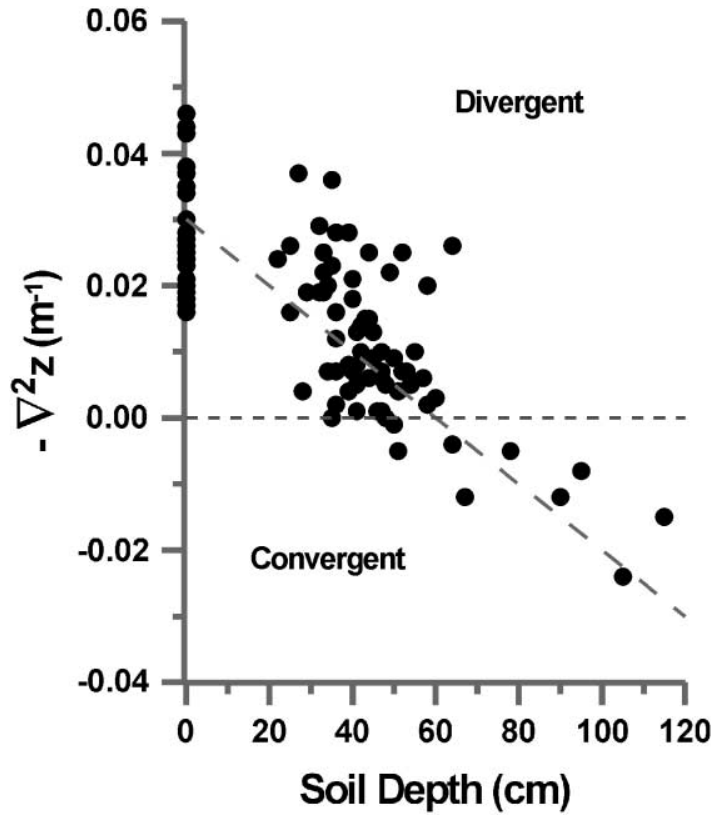

Fig. 9. Negative topographic curvature as plotted in Fig. 8 plotted against the measured normal soil depth from separate soil pits at each of the points shown by the filled circles on Fig. 4. The absence of observed depths between exposed rock and about $25 \mathrm{~cm}$ is real. The dashed gray line is not a fit to these data, but shows instead the fit to the data from Heimsath et al. (in press) from a field site at the base of the escarpment.

the usage of Eq. (3) as a basis for modeling soil thickness in relation to topography.

\subsection{Predicted soil thickness}

We used the numerical model outlined in Section 4.3, based on Eq. (3), to predict spatial variation of soil depth and the emergence of tors across the landscape. Results are shown here for a model run starting with zero initial soil depth, using Eq. (5) for the soil production function, and a diffusivity, $K=40 \mathrm{~cm}^{2} \mathrm{yr}^{-1}$ from Heimsath et al. (in press). Predicted depths after 10,000 years (Fig. 10) agree reasonably well with observed depths (Fig. 11). The predicted depths were shallower than observed prior to 10,000 years and became progressively thicker than the observed until the model reached steady-state depths at about 20,000 years. This procedure is, however, contrary to the steady-state assumption used to calculate the soil production rates in Fig. 5 and resulting in Eq. (5) (i.e. local soil depth changes with time). Recalculating soil production rates with soil depth increasing, as in this model, leads to reduced rates inferred for soil production. Logically, the two procedures could be iterated to yield best-fit estimates of a soil production function and of soil depth variation that are likely to converge. The assumed depth and rate of Late Pleistocene soil stripping will, however, affect any such solution. The

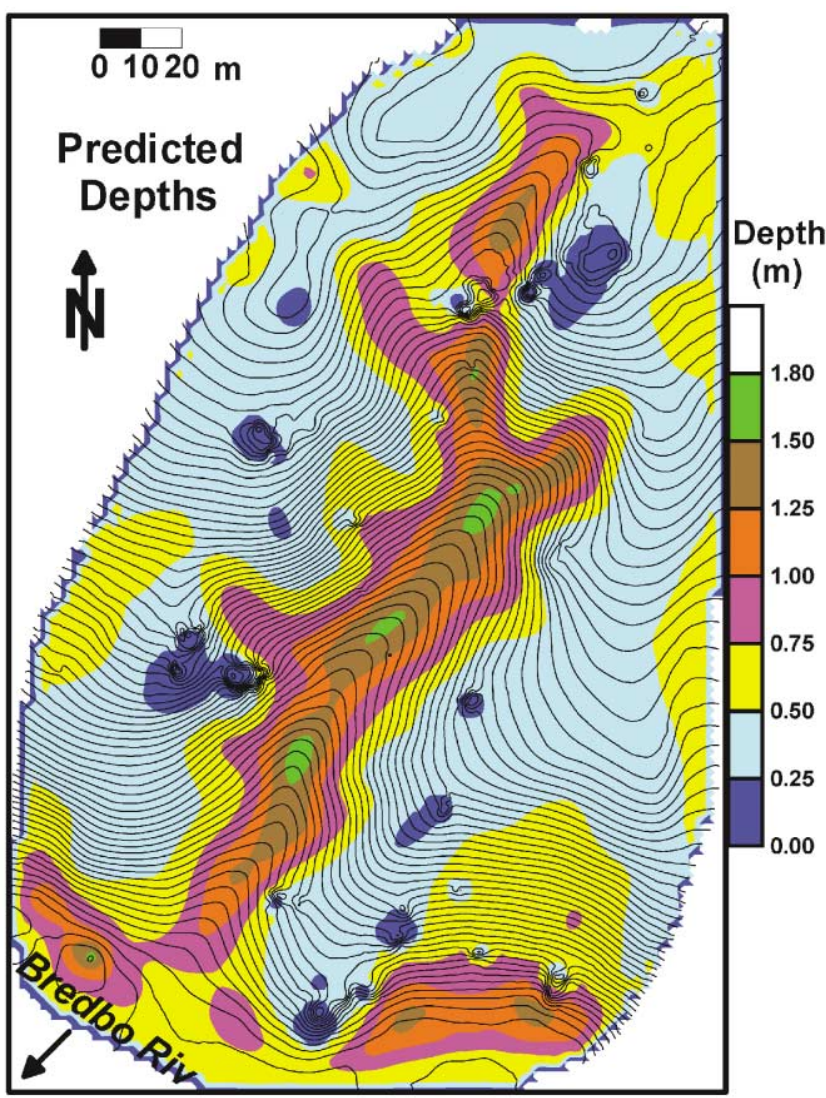

Fig. 10. Soil depths (contoured in color in $\mathrm{m}$ ) predicted after 10,000 years of running a simple landscape evolution model from Dietrich et al. (1995) as applied in Heimsath et al. (1999). Eq. (5) in the text defined the soil production function, and a diffusivity of $40 \mathrm{~cm}^{2} \mathrm{yr}^{-1}$ was used from Heimsath et al. (in press) to solve Eq. (3) by finite differences with time steps of 10 years.

tor data, presented above, indicate that stripping occurred at least at some sites, which would also lead to overestimation of soil production rates. Thus, the apparent soil production data (Eq. (5)) can be adopted as an interim upper estimate of a soil production function for $\mathrm{FH}$, but is examined further, in the discussion section.

\subsection{Stream incision and average erosion rates}

Concentrations of both ${ }^{10} \mathrm{Be}$ and ${ }^{26} \mathrm{Al}$ from three samples of the polished bedrock bed of the Bredbo River yield a consistent set of erosion rates using the solution to Eq. (2): $8.8 \pm 0.6,8.7 \pm 0.6$, and $9.5 \pm 0.7 \mathrm{~m}$ $\mathrm{Myr}^{-1}$ (BRK on Fig. 5; Table 1). A sample from a tor approximately $5 \mathrm{~m}$ uphill from the river yielded an erosion rate of $12.5 \mathrm{~m} \mathrm{Myr}^{-1}$, which is somewhat higher than the rates inferred from the riverbed samples and may reflect the subaerial weathering of the tor. The three samples from the current bed of the Bredbo River yield an average erosion rate of $9 \pm 1 \mathrm{~m} \mathrm{Myr}^{-1}$. We interpret this rate as the average bedrock downcutting rate of the 


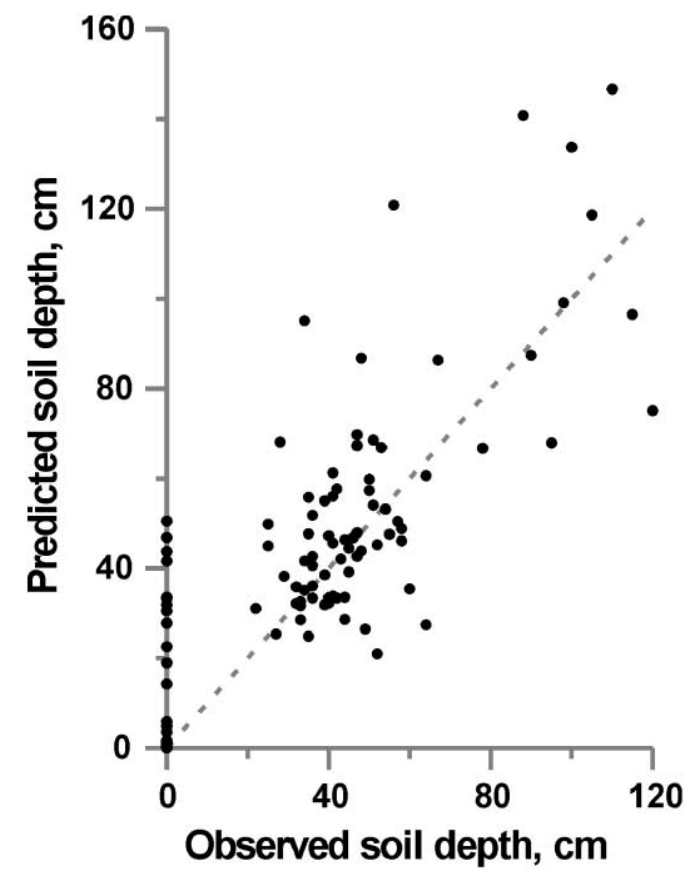

Fig. 11. Predicted soil depths from the model results mapped on Fig. 10 plotted against observed depths for each of the filled circles, except tor surfaces, located on Fig. 4. The gray dashed line is a 1 to 1 correlation, not the best fit to the data.

river based on the absence of other processes (e.g. debris flows) eroding the bedrock bed.

Catchment average erosion rates, estimated from radionuclide analyses of river sand, were $15 \pm 1$ and $16 \pm 1 \mathrm{~m} \mathrm{Myr}^{-1}$, from the Bredbo River (Riv) and from the surveyed basin (C) respectively (Fig. 5). These average erosion rates are higher than the inferred bedrock incision rate of the Bredbo River and are lower than the highest apparent soil production rates. The latter are, however, likely to be higher than the actual rates (Section 6.4, above), whereas the sand samples, having passed through the entire denudation cycle, are less affected by departures from steady state and thus give more robust estimates of average erosion rate.

\section{Discussion and conclusions}

We have applied several different analyses to deduce the rates and potential processes of erosion at the $\mathrm{FH}$ field site. Morphometric measurements determined that a simple creep law for sediment transport is an appropriate one to use as a basis for modeling the evolution of the landscape. This modeling relied on soil production and tor erosion rates inferred from cosmogenic nuclide measurements, and led to predicting the effect of corestones as incipient tors on the spatial variation of soil depth across the landscape. Nuclidebased rates were determined from saprolite beneath the soil mantle, emergent tor surfaces, bedrock in the current river channel, and sediment samples. Every sample yields a rate related to the others and here we discuss some of these couplings to draw conclusions applicable for the southeastern highlands. We first discuss the potential non-steady-state scenarios suggested by our analyses, then suggest what our best estimates for the erosion rates are and how they relate to the way the southeastern highlands have evolved over the Late Quaternary.

\subsection{Departures from steady state: (I) tors}

Whether or not the field evidence reported by other workers for episodic processes (e.g. van Dijk, 1959; Walker, 1962; Coventry and Walker, 1977; Prosser et al., 1994) can be correlated with regional events in the manner proposed by Butler (1959) is not critical to interpreting the data reported here. Geomorphic processes active on hillslopes are dependent on the biota of the region and the climate, and it is likely that the lower temperatures of the glacial cycles (by 6-9 ${ }^{\circ} \mathrm{C}$, Galloway, 1965; Caine and Jennings, 1968) led to treeless subalpine conditions and periglacial slope processes on the southeastern highlands. It has not been demonstrated unequivocally that such conditions necessarily mean higher erosion rates, or more variable processes across the highlands, but the interpretation of our nuclide samples from a tor profiles indicate that at least one episode of rapid erosion occurred.

The results from nuclide analyses of stream and catchment sediments indicate that the average denudation rate for $\mathrm{FH}$ is about $15 \mathrm{~m} \mathrm{Myr}^{-1}$. Nuclide measurements from saprolite suggest that soil production rates decrease exponentially with soil thickness and range from about 10 to $100 \mathrm{~m} \mathrm{Myr}^{-1}$, depending on the overlying soil thickness. Conversely, the nuclide concentrations from tors, other than highly weathered examples, yield bare rock erosion rates of less than $4 \mathrm{~m} \mathrm{Myr}^{-1}$. In a steady-state scenario, there is no incompatibility between low rates of tor erosion and more rapid rates of soil production; tors emerge because they erode more slowly and then eventually split or exfoliate to ultimately disintegrate. However, in several respects these results are incompatible with the assumption that erosion and soil production have been in steady state.

Perhaps the most obvious evidence against steady state is seen in the tor profile data, where the observed near-uniform nuclide concentrations depart conspicuously from a concentration profile expected under steady-state conditions (Fig. 6). The dashed line indicates the expected nuclide concentration profile if the ground surface were lowering at a constant rate and if the tor surface began eroding at a much slower rate as it emerged progressively from the ground. Instead, 
observed nuclide concentrations are roughly equal for the entire profile. The simplest explanation for this departure of the observed concentration profile from the predicted, and one supported by model calculations, is that rapid emergence of the entire tor was followed by a period of no further lowering of the ground surface. Roughly equal nuclide concentrations indicate roughly equal exposure ages if the tor surface erodes at the same rate everywhere once exposed. Field observations show no signs of exfoliation sheets or discontinuities in the exposed bedrock and suggest that the sampled surfaces have eroded at similar rates.

The effective exposure ages of the profile samples can indicate the time elapsed since rapid exhumation if the tor surface has not eroded (effective exposure age is the time to accumulate the observed nuclide concentrations in a surface sample with negligible erosion and roughly equals the observed concentration divided by the nuclide production rate if the radioactive decay rate is neglected: Lal, 1991). If the rock surface is eroding, as it inevitably must be, the time taken to accumulate observed nuclide concentrations is longer. Exposure ages of these samples (Table 1) suggest that rapid exhumation of the tor profile occurred about 150,000 years ago. Revisions in the nuclide production rates are, however, likely to reduce the nuclide production rates we used (e.g. Clark et al., 1995; Nishiizumi et al., 1996; Stone et al., 1998a; Dunai, 2000), which would increase this effective exposure age, although this may be offset by the increased nuclide production by muons (e.g. Stone et al., 1998a).

Despite these factors, we can place better limits on the time since exhumation, and on the rates of both soil denudation prior to exhumation and tor erosion since exhumation, by numerical modeling as outlined in Section 4.4 and illustrated by Fig. 3. By modeling various scenarios for tor emergence (i.e. different pre and post-exhumation erosion rates as well as different times for the onset of exhumation) we found that the observed nuclide concentrations of the tor profile could only be generated if a period of rapid exhumation occurred more than 150,000 years ago with very low rates of both prior denudation and post-exhumation tor erosion $\left(<1 \mathrm{~m} \mathrm{Myr}^{-1}\right)$. If higher tor erosion rates were used in the model then the time since the onset of exhumation necessary to generate the observed concentrations becomes longer; e.g., rates of $2 \mathrm{~m} \mathrm{Myr}^{-1}$ require exhumation 250,000 years ago, to reproduce the observed concentrations.

This result for the tor profile does not imply that all tors were exhumed at the same time. Apparent exposure ages (Table 1) suggest that exhumation of the measured tors and ground-level rock exposure occurred at various times between about 20,000 and 160,000 years ago. As with the tor profile, the actual exhumation times will be greater and will depend on pre and post exhumation erosion rates. The results also do not imply that tor emergence is an indicator of past periods of episodic exhumation. An example from the coastal lowlands measured concentrations that supported a steady-state emergence model for the tor (Heimsath et al., in press). However, because of the nearly equal nuclide concentrations from the tor profile measured at $\mathrm{FH}$ it appears undeniable that one or more episodes of tor exhumation under accelerated erosion occurred in the last 300,000 years.

\subsection{Departures from steady state: (II) soil production}

A phase of rapid denudation (or "stripping") is contrary to the steady state assumption used to determine soil production rates, and rates calculated by Eq. (5) will be too high. For example, if two meters of stripping from 30 to 20,000 years ago was preceded and followed by actual erosion rates of $10 \mathrm{~m} \mathrm{Myr}^{-1}$, the nuclide concentrations observed at today's ground surface would suggest an apparent rate of nearly $30 \mathrm{~m} \mathrm{Myr}^{-1}$. Such discrepancies decrease as the time since stripping increases. If the major stripping episode was at or before 150,000 years ago, as the tor profile data suggest, then the effect on our soil production rates (Fig. 5) is negligible.

Several features of the data suggest that our apparent soil production rates are too high, however. Eq. (5) yields a rate of $143 \mathrm{~m} \mathrm{Myr}^{-1}$ when soil cover is zero, which is more than double the intercept of $53 \mathrm{~m} \mathrm{Myr}^{-1}$ for the better-defined production function determined by Heimsath et al. (in press) at their Bega Valley site (Fig. 12), and is much higher than apparent rates for any samples measured from FH (Fig. 5 and Table 1). The apparent soil production rates in Fig. 5 also lead to higher than observed apparent denudation rates for bedrock at ground surface. The apparent rates observed for exposures FH-3 and 10 (19 and $26 \mathrm{~m} \mathrm{Myr}^{-1}$, respectively) are lower than expected under steady-state exhumation. That is, if the observed soil depths of about $30 \mathrm{~cm}$ surrounding these samples are an indication of the soil thickness that covered FH-3 and 10 until their recent emergence as bedrock surfaces then Fig. 5 would suggest that rates between 35 and $40 \mathrm{~m} \mathrm{Myr}^{-1}$ would be the inferred soil production rates.

Furthermore, as noted earlier, our assumption of steady state for calculating soil production rates is contrary to our model simulation of soil cover at $\mathrm{FH}$ (Fig. 10), which commenced with zero soil cover and reasonably predicted observed depths after 10,000 years (Fig. 11). Because the best match between predicted and observed soil depths is reached prior to the spatial variation of soil depth reaching approximate steady state (at $\sim 20,000$ years), the modeling results suggest that the soil mantle is evolving and adjusting to the site topography. If this is the case and the observed soil 


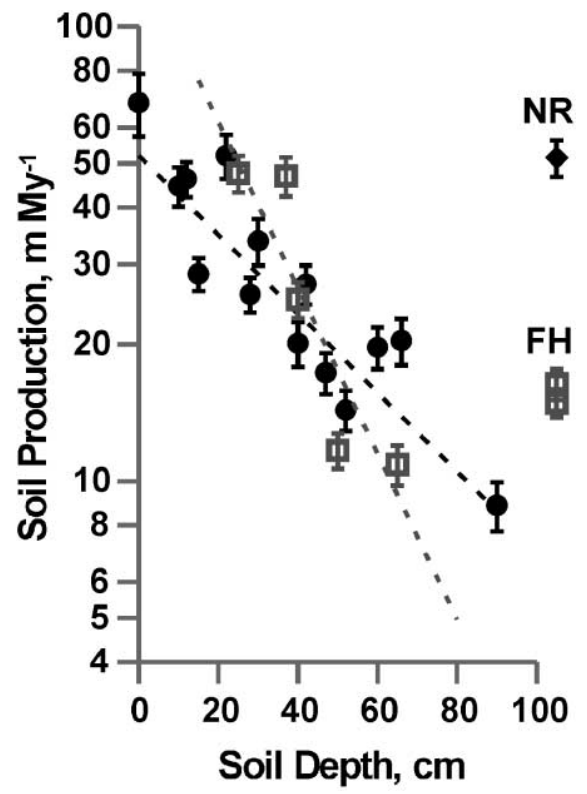

Fig. 12. Soil production functions from both the Frogs Hollow site (gray open squares as plotted by filled circles on Fig. 5) and the Nunnock River (NR) site from Heimsath et al. (in press) showing the remarkable similarity in rates as well as the differences in the exponential best fits to the data. The apparent function for $\mathrm{FH}$ is defined in the text, while the NR data, also from both ${ }^{10} \mathrm{Be}$ and ${ }^{26} \mathrm{Al}$ concentrations in bedrock and saprolite underlying the observed soil depths, defines a soil production function of, $\varepsilon(H)=$ $(53 \pm 3) \mathrm{e}^{-(0.020 \pm 0.001) H}$, where the terms are the same as in the text here. Average erosion rates from stream sediments (NR, black diamond) and both the Bredbo River and catchment sediments (FH, gray open squares) are plotted to the right of the soil depth axis.

depths have not been relatively constant for the exposure history of our saprolite samples, then our inferred soil production rates are likely to be incorrectly modeled. Namely, we have assumed that the observed soil cover has dampened nuclide production rates for entire exposure history of the saprolite samples. If the soil thickness was thinner or nonexistent over the exposure history of the samples, then the actual nuclide production rates would have been higher and the inferred soil production rates would be higher by the solution to Eq. (2). If, however, the observed soil depths reflect an evolution from a period of rapid stripping and prior to that stripping the landscape was mantled with soil similar or greater than the present level, then the long-term nuclide production rates are likely to be similar to those reported here.

Rates given by our apparent soil production function for FH could be revised if the stripping history for the soil cover was better known, but is not possible from available data. Basin-average rates inferred from sand samples $C$ and Riv (Fig. 5) suggest that the apparent denudation rates of the soil production function are too high, and therefore that the corrected nuclide production rates for the saprolite samples are too high. Modest stripping at the end of the Pleistocene would go some way to reconciling apparent rates from bedrock outcrops and saprolite samples. If steady-state denudation were punctuated by one meter of stripping between 25 and 20,000 years ago, a true pre- and post-event rate of $10 \mathrm{~m} \mathrm{Myr}^{-1}$ would lead to an apparent rate of $22 \mathrm{~m} \mathrm{Myr}^{-1}$, for example. The slope of the fitted line in Fig. 5 would be lowered, as would the extrapolated zero soil-depth production rate. Calculated values for soil production rates would be reduced further if the regenerating soil were known to have increased in depth after the stripping event. Collectively, these factors would reduce the differences between the apparent soil production rates and the rates given by sand samples $C$ and Riv.

One line of evidence that may show at least one period of elevated erosion, or rejuvenation, acting across the landscape is suggested by the knickpoints evident in the Bredbo River long profile, upstream of the field area (Fig. 1). Knickpoints in both upstream branches of the Bredbo occur at the same distance and do not reflect any local lithological variation in the underlying granite. Although we have no age constraint on when this knickpoint is likely to have propagated up the Bredbo, it is reasonable to suggest that its propagation through the field area could have sent a pulse of incision into the differentially weathered landscape and resulted in the formation of the FH sub-catchment. Higher erosion rates driven by the sudden drop in local base level began stripping the saprolite and the corestones emerged as tors. The soil production rates measured from the saprolite may indicate that the catchment is still responding to such a pulse of incision.

\subsection{Best-estimates of Late Quaternary rates at Frogs Hollow}

A catchment average denudation rate can be derived by summing the apparent rates calculated by the soil production function across the landscape, including the proportional contribution of exposed tors, duly taking soil depth into account at each point. Using the apparent soil production function (Eq. (5)), combined with observed soil depths leads to estimating an average rate of 25-35 $\mathrm{m} \mathrm{Myr}^{-1}$ for the catchment, which almost certainly is too high owing to the factors discussed above (i.e. the stripping episodes). Conversely, the bedrock incision rate of about $9 \mathrm{~m} \mathrm{Myr}^{-1}$ from the Bredbo is likely to be lower than the average rate from a catchment responding to knickpoint propagation. The average rate by the sand sample, Riv $\left(15 \mathrm{~m} \mathrm{Myr}^{-1}\right)$ may be somewhat low, owing to potential nuclide production during transport from soil to river, but it is unlikely that transport time for the catchment sediment, C $\left(16 \mathrm{~m} \mathrm{Myr}^{-1}\right)$, was significant. We conclude that the basin average rate for $\mathrm{FH}$ is in the range 
15-25 $\mathrm{m} \mathrm{Myr}^{-1}$, reflecting the lower bound of the soil production rates and favoring the average rate inferred from the sand samples.

This result clearly applies only for the Late Quaternary Period. At $15-25 \mathrm{~m} \mathrm{Myr}^{-1}$, the observed soil cover could be generated in less than 30,000 years (our modeling based on the higher rates of our apparent soil production function indicated generation of the soil mantle in 10,000 years). Late Quaternary denudation rates may have been periglacially accelerated, however, and rate estimates over longer periods are desirable. The tor profile data can be used for this purpose. Nuclide data from a tor profile indicate that the entire $2.5 \mathrm{~m}$ tor was exposed 150,000 or more years ago. Although the tor represents stepwise rather than uniform denudation, in terms of averages the result indicates a rate of about $17 \mathrm{~m} \mathrm{Myr}^{-1}(2.5 \mathrm{~m} / 0.15 \mathrm{Myr})$. This estimate is from only one point, but does not conflict with the uppermost Quaternary range of $15-25 \mathrm{~m} \mathrm{Myr}^{-1}$, which we conclude is a representative rate of landscape denudation at $\mathrm{FH}$ for the last 30,000 and perhaps the last 150,000 years. We also conclude that denudation rates fluctuated through cycles of stripping and soil regeneration.

\subsection{The changing pace of landscape evolution}

Late Quaternary rates reported here are more rapid than rates estimated for southeast Australian highlands over longer timescales. Stephenson and Lambeck (1985) and Lambeck and Stephenson (1986) argued that the southeastern highlands have evolved since the Palaeozoic and showed that long-term erosion rates of $1-5 \mathrm{~m} \mathrm{Myr}^{-1}$ were consistent with isostatically-driven development of the highlands. Slow rates of Tertiary channel erosion were deduced for the southeastern highlands by several studies that divided the age of plateau-forming basalts into the elevation difference between the flows and the channels that had incised through them (Wellman and McDougall, 1974; Wellman, 1979, 1987; Bishop, 1985, 1986; Bishop et al., 1985). Calculated rates from these studies were less than $10 \mathrm{~m} \mathrm{Myr}^{-1}$, although these are a minimum due to unmeasured erosion of the basalt surfaces. Apatite fission track thermochronology from the southeastern highlands suggests rapid uplift and erosion in the Cretaceous Period, associated with Tasman Sea rifting, and that present morphologies were established about $60 \mathrm{Myr}$ ago (e.g. Dumitru et al., 1991; Brown et al., 1994; O'Sullivan et al., 1995, 1996). On a shorter time scale, Seidl et al. (1996) and Weissel and Seidl (1997, 1998) used a mass balance approach and cosmogenic nuclide measurements to determine denudation rates near the eastern margin of the New England tablelands. They found low rates of erosion from the highland region $\left(\sim 4 \mathrm{~m} \mathrm{Myr}^{-1}\right)$. Higher rates were measured near the upper edge of the escarpment $\left(\sim 20 \mathrm{~m} \mathrm{Myr}^{-1}\right)$ and across the gorge head $\left(\sim 100 \mathrm{~m} \mathrm{Myr}^{-1}\right)$, although processes at these steep gorge sites are not comparable with those of the highlands proper.

In conclusion, results from several independent approaches reported here suggest that landscape denudation of the southeastern highlands accelerated in upper Quaternary times (15-25 $\mathrm{m} \mathrm{Myr}^{-1}$ compared to Tertiary rates of less than $10 \mathrm{~m} \mathrm{Myr}^{-1}$ ). If this is indeed the case, then the $15-25 \mathrm{~m} \mathrm{Myr}^{-1}$ denudation rates of the uplands are significantly higher than the average stream incision rate of $9 \mathrm{~m} \mathrm{Myr}^{-1}$, and would suggest that the highlands are in a state of downwearing ( $c f$ Davis, 1899) at least since upper Quaternary times. Finally, the soil stripping phases suggested by the tor data are likely to have occurred repeatedly during this time, but probably correspond to times of periglacially accelerated denudation, or to drops in catchment baselevel associated with knickpoint propagation. Data from the single tor profile indicates that a significant stripping phase may have occurred about 150,000 years ago that was more dramatic than any similar process within the last glacial cycle. It appears more than coincidence that this inference corresponds with the major phase of aeolian erosion of 180-140,000 years ago, documented from Tasman Sea cores (Hesse, 1994), which exceeded in duration and intensity the denudation records from the last glacial cycle. We also find, using a numerical model to reasonably predict the spatial variation of soil depth developed after 10,000 years, that the landscape might be recovering from a relatively recent period of stripping.

\section{Summary}

Cosmogenic nuclide concentrations in saprolite beneath a spatially variable soil cover infer soil production rates from 11 to $50 \mathrm{~m} \mathrm{Ma}^{-1}$ and suggest a steep, negative exponential soil production function. While these rates are similar to those from a very different site on the coastal lowlands, they are higher than rates suggested by others for the highlands. Nuclide concentrations from a profile of tor samples are best interpreted to show evidence for a period of rapid denudation at least 150,000 years ago and infer a rate of about $4 \mathrm{~m} \mathrm{Ma}^{-1}$ for the exposed bedrock. Furthermore, a numerical model predicts the partial emergence of tors and the development of the observed soil mantle after only 10,000 years, suggesting the potential for a more recent period of stripping. Bedrock incision rates determined from samples of the Bredbo River bed are about $9 \mathrm{~m} \mathrm{Ma}^{-1}$, lower than the catchment-averaged rates of about $16 \mathrm{~m} \mathrm{Ma}^{-1}$, inferred from nuclide concentrations measured in sediments, but similar to long-term rates found 
by others. We conclude that the upland erosion rates of about $15-25 \mathrm{~m} \mathrm{Myr}^{-1}$ are in response to periods of accelerated erosion and that the landscape is slowly adjusting towards a new steady-state.

\section{Acknowledgements}

Peter Fogarty helped locate the FH site and ensured it was Crown Land. Thanks to Geoff Hunt for helping to survey the site and Rachel Butterworth for helping with preliminary sample processing and bulk density measurements at CSIRO. Cathy Wilson and Ian Prosser assisted for the fieldwork logistics with CSIRO support. NSF grant, EAR-9527006, Cal Space, IGPP-LLNL GS96-05, and NASA Global Change and Switzer Environmental fellowships to Heimsath supported this work. Nuclide measurements were partially performed under the auspices of the US DOE by Lawrence Livermore National Laboratory under contract W-7405Eng-48, and we thank Don DePaolo for laboratory space.

\section{References}

Bierman, P.R., 1994. Using in situ produced cosmogenic isotopes to estimate rates of landscape evolution; a review from the geomorphic perspective. Journal of Geophysical Research, B, Solid Earth and Planets 99 (7), 13885-13896.

Bierman, P., Steig, E.J., 1996. Estimating rates of denudation using cosmogenic isotope abundances in sediment. Earth Surface Processes and Landforms 21, 125-139.

Bishop, P., 1985. Southeast Australian late Mesozoic and Cenozoic denudation rates: a test for late Tertiary increases in continental denudation. Geology 13, 479-482.

Bishop, P., 1986. Horizontal stability of the Australian continental drainage divide in south central New South Wales during the Cainozoic. Australian Journal of Earth Sciences 33, 295-307.

Bishop, P., Brown, R., 1992. Denudational isostatic rebound of intraplate highlands: the Lachlan River valley, Australia. Earth Surface Processes and Landforms 17 (4), 345-360.

Bishop, P., Young, R.W., McDougall, I., 1985. Stream profile change and longterm landscape evolution; early Miocene and modern rivers of the East Australian highland crest, central New South Wales, Australia. Journal of Geology 93 (4), 455-474.

Bowler, J.M., 1967. Quaternary geology of Goulburn Valley sediments and their correlation in south-eastern Australia. Journal of the Geological Society of Australia 14, 287-292.

Brown, R.W., Summerfield, M.A., Gleadow, A.J.W., 1994. Apatite fission track analysis: its potential for the estimation of denudation rates and implications for models of long term landscape development. In: Kirby, M.J. (Ed.), Process Models and Theoretical Geomorphology. Wiley, Chichester, pp. 23-53.

Brown, E.T., Bourles, D.L., Colin, F., Raisbeck, G.M., Yiou, F., Desgarceaux, S., 1995. Evidence for muon-induced production of ${ }^{10} \mathrm{Be}$ in near-surface rocks from the Congo. Geophysical Research Letters 22 (6), 703-706.

Bureau of Meteorology, Australia, 1999. Climate averages for Nimmitabel, NSW, 1894-1996. Data posted on the Web: http:// www.bom.gov.au/climate/averages/.
Butler, B.E., 1959. Periodic phenomena in landscapes as a basis for soil studies. CISRO Australia Soil Publication, 14.

Butler, B.E., 1967. Soil periodicity in relation to landform development in southeastern Australia. In: Jennings, J.N., Mabbutt, J.A. (Eds.), Landform Studies from Australia and New Guinea. Cambridge University Press, Cambridge, pp. 231-255.

Caine, N., Jennings, J.N., 1968. Some blockstreams of the Toolong Range, Kosciusko State Park, New South Wales. Proceedings of the Royal Society of New South Wales 101, 93-103.

Carson, M.A., Kirkby, M.J., 1972. Hillslope Form and Process. Cambridge University Press, New York, 475pp.

Cerling, T.E., Craig, H., 1994. Geomorphology and in-situ cosmogenic isotopes. Annual Review of Earth and Planetary Sciences 22, 273-317.

Clark, D.H., Bierman, P.R., Larsen, P., 1995. Improving in situ cosmogenic chronometers. Quaternary Research 44, 367-377.

Costin, A.B., 1972. Carbon-14 dates from the Snowy Mountains area and their interpretation. Quaternary Research 2, 579-590.

Costin, A.B., Polach, H.A., 1971. Slope deposits in the Snowy Mountains, south-eastern Australia. Quaternary Research 1, 228-235.

Coventry, R.J., Walker, P.H., 1977. Geomorphological significance of Late Quaternary Deposits of the Lake George area, N.S.W. Australian Geographer 13 (6), 369-376.

Cressie, N.A.C., 1991. Statistics for spatial data. John Wiley and Sons, Inc., New York, 900pp.

Davis, W.M., 1892. The convex profile of badland divides. Science 20, 245.

Davis, W.M., 1899. The geographical cycle. Geographical Journal 14, 481-245504.

Davis, J.C., et al., 1990. LLNL/UC AMS facility and research program. Nuclear Instruments Methods in Physics Research Section B (B52), 269-272.

Dietrich, W.E., Reiss, R., Hsu, M-L., Montgomery, D.R., 1995. A process-based model for colluvial soil depth and shallow landsliding using digital elevation data. Hydrological Processes 9, 383-400.

Dumitru, T.A., Hill, K.C., Coyle, D.A., Duddy, I.R., Foster, D.A., Gleadow, A.J.W., Green, P.F., Kohn, B.P., Laslett, G.M., O'Sullivan, A.J., 1991. Fission track thermochronology; application to continental rifting of south-eastern Australia. In: Hinkins, J.A.C. (Ed.), 1991 APEA conference. The APEA Journal, Melbourne, Australia, pp. 131-142.

Dunai, T.J., 2000. Scaling factors for production rates of in situ produced cosmogenic nuclides: a critical reevaluation. Earth and Planetary Science Letters 176, 157-169.

Dunne, J., Elmore, D., Muzikar, P., 1999. Scaling factors for the rates of production of cosmogenic nuclides for geometric shielding and attenuation at depth on sloped surfaces. Geomorphology 27 (1-2), $3-11$.

Galloway, R.W., 1965. Late Quaternary climates in Australia. Journal of Geology 73, 603-618.

Gilbert, G.K., 1877. Report on the Geology of the Henry Mountains (Utah). United States Geological Survey, Washington, D.C.

Gilbert, G.K., 1909. The convexity of Hilltops. Journal of Geology 17 (4), 344-350.

Gilchrist, A.R., Summerfield, M.A., 1990. Differential denudation and flexural isostasy in formation of rifted-margin upwarps. Nature 346 (6286), 739-742.

Granger, D.E. and Smith, A.L., 2000. Dating buried sediments using radioactive decay and muogenic production of ${ }^{26} \mathrm{Al}$ and ${ }^{10} \mathrm{Be}$. Nuclear Instrumentation and Methods in Physics Research B 172, $822-826$.

Hack, J.T., 1960. The interpretation of erosional topography in humid temperate regions. American Journal of Science 258A, $80-97$. 
Hayes, D.E., Ringis, J., 1973. Seafloor spreading in the Tasman Sea. Nature 243, 454-458.

Heimsath, A.M., Dietrich, W.E., Nishiizumi, K., Finkel, R.C., 1997. The soil production function and landscape equilibrium. Nature 388, 358-361.

Heimsath, A.M., Dietrich, W.E., Nishiizumi, K., Finkel, R.C., 1999. Cosmogenic nuclides, topography, and the spatial variation of soil depth. Geomorphology 27, 151-172.

Heimsath, A.M., Chappell, J., Dietrich, W.E., Nishiizumi, K., Finkel, R.C., 2001. Soil production on a retreating escarpment in southeastern Australia. Geology 28 (9), 787-790.

Hesse, P.P., 1994. The record of continental dust from Australia in Tasman Sea sediments. Quaternary Science Reviews 13 (3), 257-272.

Kohl, C.P., Nishiizumi, K., 1992. Chemical isolation of quartz for measurement of in-situ-produced cosmogenic nuclides. Geochimica et Cosmochimica Acta 56, 3583-3587.

Lal, D., 1988. In situ-produced cosmogenic isotopes in terrestrial rocks. Annual Review of Earth and Planetary Sciences 16, 35-388.

Lal, D., 1991. Cosmic ray labeling of erosion surfaces: in situ nuclide production rates and erosion models. Earth and Planetary Science Letters 104, 424-439.

Lal, D., Arnold, J.R., 1985. Tracing quartz through the environment. Proceedings of the Indian Academy of Sciences (Earth and Planetary Sciences) 94 (1), 1-5.

Lambeck, K., Stephenson, R., 1986. The post-Palaezoic uplift history of south-eastern Australia. Australian Journal of Earth Sciences $33,253-270$.

Linton, D.L., 1955. The problem of tors. Geographical Journal 121, 470-487.

Masarik, J., Kollar, D., Vanya, S., 2000. Numerical simulation of insitu production of cosmogenic nuclides: effects of irradiation geometry. Nuclear Instrumentats and Methods in Physics Research B $172(1-4), 786-789$.

Moore, M.E., Gleadow, A.J.W., Lovering, J.F., 1986. Thermal evolution of rifted continental margins; new evidence from fission tracks in basement apatites from southeastern Australia. Earth and Planetary Science Letters 78 (2-3), 255-270.

Nishiizumi, K., Lal, D., Klein, J., Middleton, R., Arnold, J.R., 1986. Production of ${ }^{10} \mathrm{Be}$ and ${ }^{26} \mathrm{Al}$ by cosmic rays in terrestrial quartz in situ and implications for erosion rates. Nature 319 (6049), 134-136.

Nishiizumi, K., et al., 1989. Cosmic ray production rates of ${ }^{10} \mathrm{Be}$ and ${ }^{26} \mathrm{Al}$ in quartz from glacially polished rocks. Journal of Geophysical Research 94 (B12), 17907-17915.

Nishiizumi, K., et al., 1991. Cosmic ray produced ${ }^{10} \mathrm{Be}$ and ${ }^{26} \mathrm{Al}$ in Antarctic rocks; exposure and erosion history. Earth and Planetary Science Letters 104 (2-4), 440-454.

Nishiizumi, K., et al., 1993. Role of in situ cosmogenic nuclides ${ }^{10} \mathrm{Be}$ and ${ }^{26} \mathrm{Al}$ in the study of diverse geomorphic processes. Earth Surface Processes and Landforms 18, 407-425.

Nishiizumi, K., Finkel, R.C., Klein, J., Kohl, C.P., 1996. Cosmogenic production of ${ }^{7} \mathrm{Be}$ and ${ }^{10} \mathrm{Be}$ in water targets. Journal of Geophysical Research 101 (B10), 22225-22232.

Nott, J.F., 1992. Long-term drainage evolution in the Shoalhaven catchment, Southeast Highlands, Australia. Earth Surface Processes and Landforms 17 (4), 361-374.

Ollier, C.D., 1978. Tectonics and geomorphology of the Eastern Highlands. In: Davies, J.L., Williams, A.J. (Eds.), Landform Evolution in Australasia. Australian National University, Canberra, pp. 5-47.

Ollier, C.D., 1982. The Great Escarpment of eastern Australia: tectonic and geomorphic significance. Journal of the Geological Society of Australia 29, 13-23.

Ollier, C.D., 1985. Morphotectonics of passive continental margins. Zeitschrift fuer Geomorphologie. Supplementband 54, 1-9.
O’Sullivan, P.B., Kohn, B.P., Foster, D.A., Gleadow, A.J.W., 1995. Fission track data from the Bathurst Batholith-evidence for rapid mid-cretaceous uplift and erosion within the eastern highlands of Australia. Australian Journal of Earth Sciences 42 (6), 597-607.

O’Sullivan, P.B., Foster, D.A., Kohn, B.P., Gleadow, A.J.W., 1996. Multiple postorogenic denudation events - an example from the eastern Lachlan Fold Belt, Australia. Geology 24 (6), 563-566.

O’Sullivan, P.B., Orr, M., O'Sullivan, A.J., Gleadow, A.J.W., 1999. Episodic Late Palaeozoic to Cenozoic denudation of the southeastern highlands of Australia: evidence from the Bogong high plains, Victoria. Australian Journal of Earth Sciences 46 (2), 199-216.

Pain, C.F., 1985. Morphotectonics of the continental margins of Australia. Zeitschrift fuer Geomorphologie. Supplementband 54, 23-35.

Paton, T.R., Humphries, G.S., Mitchell, P.B., 1995. Soils: A New Global View. UCL Press Limited, London, 213pp.

Prosser, I.P., Chappell, J., Gillespie, R., 1994. Holocene valley aggradation and gully erosion in headwater catchments, southeastern highlands of Australia. Earth Surface Processes and Landforms 19 (5), 465-480.

Richardson, S.J., 1976. Geology of the Michelago 1:100,000 sheet 8726. Geological Survey of New South Wales, Department of Mineral Resources and Development, Canberra, Australia, $253 \mathrm{pp}$

Seidl, M.A., Weissel, J.K., Pratson, L.F., 1996. The kinematics and pattern of escarpment retreat across the rifted continental margin of SE Australia. Basin Research 8 (3), 301-316.

Small, E.E., Anderson, R.S., Hancock, G.S., 1999. Estimates of the rate of regolith production using ${ }^{10} \mathrm{Be}$ and ${ }^{26} \mathrm{Al}$ from an alpine hillslope. Geomorphology 27 (1-2), 131-150.

Stephenson, R., Lambeck, K., 1985. Erosion-isostatic rebound models for uplift; an application to south-eastern Australia. The Geophysical Journal of the Royal Astronomical Society 82 (1), 31-55.

Stone, J.O., Ballantyne, C.K., Fifield, L.K., 1998a. Exposure dating and validation of periglacial weathering limits, northwest Scotland. Geology 26 (7), 587-590.

Stone, J.O., Evans, J.M., Fifield, L.K., Allan, G.L., Cresswell, R.G., 1998b. Cosmogenic chlorine-36 production in calcite by muons. Geochimica et Cosmochimica Acta 62 (3), 433-454.

Twidale, C.R., 1985. Granite landform evolution; factors and implications, Hans Cloos Kolloquim. Geologische Rundschau, Bonn, DEU, pp. 769-779.

van der Beek, P., Braun, J., 1998. Numerical modelling of landscape evolution on geological time-scales: a parameter analysis and comparison with the south-eastern highlands of Australia. Basin Research 10, 49-68.

van Dijk, D.C., 1959. Soil features in relation to erosional history in the vicinity of Canberra. CSIRO Soil Publication, 14, Canberra.

Walker, P.H., 1962. Soil layers on hillslopes: a study at Nowra, N.S.W. Australian Journal of Soil Science 13, 167-177.

Weissel, J.K., Hayes, D.E., 1977. Evolution of the Tasman Sea reappraised. Earth and Planetary Science Letters 36 (1), 77-84.

Weissel, J.K., Seidl, M.A., 1997. Influence of rock strength properties on escarpment retreat across passive continental margins. Geology 25 (7), 631-634.

Weissel, J.K., Seidl, M.A., 1998. Inland propagation of erosional escarpments and river profile evolution across the southeast Australian passive continental margin. In: Tinkler, K.J., Wohl, E.E. (Eds.), Rivers Over Rock: Fluvial Processes in Bedrock Channels. Geophysical Monograph, American Geophysical Union, Washington, DC. 
Wellman, P., 1979. On the Cainozoic uplift of the southeastern Australian highland. Journal of the Geological Society of Australia 26, 1-9.

Wellman, P., 1987. Eastern highlands of Australia; their uplift and erosion. BMR Journal of Australian Geology and Geophysics 10, 277-286.
Wellman, P., McDougall, I., 1974. Potassium-Argon ages on the Cainozoic volcanic rocks of New South Wales. Journal of the Geological Society of Australia 21 (3), 247-272.

Williams, A.G., Ternan, L., Kent, M., 1986. Some observations on the chemical weathering of the dartmoor granite. Earth Surface Processes and Landforms 11, 557-574. 